
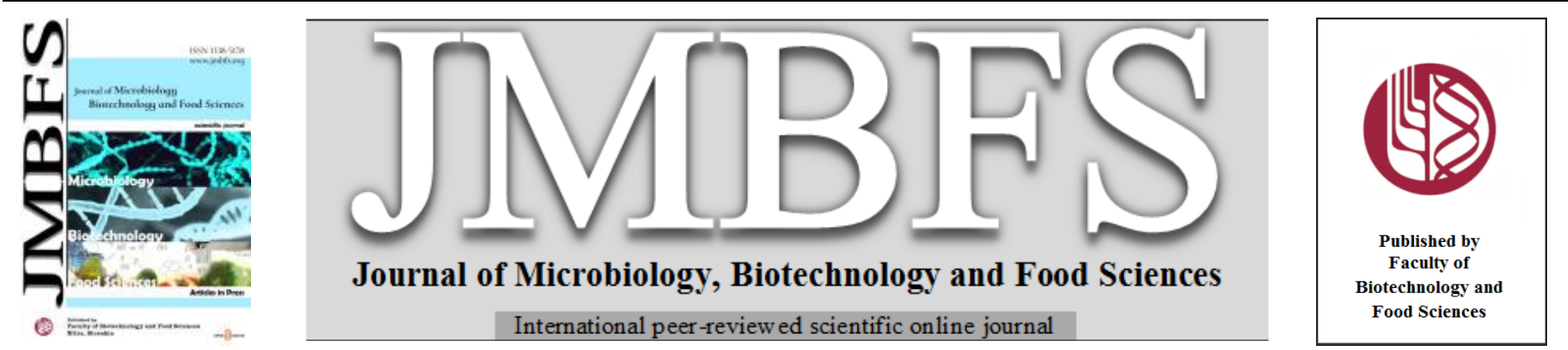

\title{
APPLICATIONS OF PLANT LECTINS IN BIOTECHNOLOGY AND THERAPEUTICS
}

\author{
Sanjay Naik, Sanjit Kumar*
}

Address(es):

Vellore Institute of Technology (VIT), Centre for Bio-Separation Technology (CBST), 632014 Vellore, Tamil Nadu, India. Tel.: +91- 4162202374

*Corresponding author: sanjitkrrroy@gmail.com sanjitkumar@vit.ac.in

https://doi.org/10.55251/jmbfs.4224

ARTICLE INFO

Received 16. 1. 2021

Revised 13. 8. 2021

Accepted 3. 9. 2021

Published 1. 2. 2022

Review

OPEN $\partial_{\text {ACCESS }}$

\begin{abstract}
Lectins are carbohydrate-binding proteins broadly used in various therapeutic and biomedical applications. The variable affinity of lectins towards variety of carbohydrates has raised attention for the biologist to explore functional aspects of lectins. Lectins express specificity to simple carbohydrates for example mannose, lactose, sialic acid, complex glycan, and glycoproteins. Lectins are classified based on their sugar specificity and are used as a tool to study protein-carbohydrate interactions. Lectins are ubiquitous in nature and identified from all sources such as bacteria, fungi, algae, and animals. Plants are the most abundant source of lectins, and till now, more than three hundred lectins were characterized from plants. These are distributed to various parts of a plant according to their requirements and function. The physiological role of lectins in a plant is still not well understood. The overabundant presence of lectins in plant seeds and storage tissues indicated their role in plant development. Plant lectins shows a broad range of activities like antibacterial, antifungal, insecticidal, anticancerous, antileishmanial, antiviral, and anticoagulants. In this review, we aim to highlight the plant lectins classification and their application in various biological aspects.
\end{abstract}

Keywords: Lectins, Plant lectins, Sugar specificity, Therapeutic aspect

\section{INTRODUCTION}

Lectins are glycoprotein with a divers function capable to bind specific carbohydrates without modifying them (Gemeiner et al., 2009). Lectins are nonimmune origin differ from antibody in many aspects. Antibodies are structurally similar exclusively present in animals whereas lectins are structurally different from each other and also present in plants and bacteria where no immunological system present (Sharon, 2008). In the late $18^{\text {th }}$ century Peter Hermann Stillmark observed that the protein from plants can agglutinate erythrocytes and it was named Phytohemagglutinin \{(Phyto (plant)+ Hemagglutinin (red blood cells agglutinate) \}(Sharon et al., 2004). These observations led to the discovery of the first phytohemagglutinin from seeds of the castor plant which was named ricin (Polito et al., 2019). In 1954 Boyd and Shapleigh recognized that phytohemagglutinins were selectively agglutinate different human blood groups $\mathrm{ABO}$, because of its sugar specificity. The selective nature of phytohemagglutinin named as lectin from the Latin verb that's means "to select" proposed by Boyd and Shapleigh (Hou et al., 2003). Lectins are isolated and characterized by almost all five kingdoms (Monera, Protista, Fungi, Plantae, and Animalia) (Naik et al., 2017). In case of plants, the source of lectins are roots, bulbs, pulps, tubers, rhizome, latex, barks, stems, leaves, flowers, fruits, and seeds (Table 1). Lectins are extracted from different parts of the plants have a wide range of applications in biochemistry, plant biology, agriculture, cell biology, immunology, virology, and biomedical field. The physiological role of lectins in plants remains unclear or controversial. Differences in structural and sugar specificity indicates lectins unlikely to have similar functions inside the plant. Insecticidal, antibacterial effect of plant lectins demonstrated that lectins play crucial role in plant defense system. More in detail lectins show potential role as antibacterial, antifungal, anti-HIV, antitumor, cytotoxic, insecticidal, immunomodulatory, vasorelaxant, histochemical, tumor detection marker, and pathology. This review is mainly on specificity, classification and application of plant lectins. $\underline{\text { Table } 1 \text { Source of plant lectins }}$

\begin{tabular}{llc}
\hline S.No. & Plants & Source \\
\hline 1 & Pinellia ternata & Tubers \\
\hline 2 & Acacia farnesiana & Seeds \\
\hline 3 & Sambucus ebulus $L$ & shoot \\
\hline 4 & mulberry & leaf \\
\hline 5 & Microgramma vacciniifolia & rhizome \\
\hline 6 & Euphorbia trigona & latex \\
\hline 7 & Hyacinth & bulbs \\
\hline 8 & Punica granatum & fruits \\
\hline 9 & Moringa oleifera & Seed cake \\
\hline 10 & Sophora flavescens & roots \\
\hline 11 & Alpinia purpurata & inflorescences \\
\hline 12 & Crataeva tapia & bark \\
\hline 13 & Cucumis sativus & phloem exudate \\
\hline
\end{tabular}

\section{Specificity and Classification of Plant lectin}

In recent years mannose-specific lectins were extensively characterized from monocot plants. Sugar specific hemagglutination inhibition assay ensured the specificity of lectins. Lonchocarpus campestris lectin (De Freitas Pires et al., 2019), Diocleinae lectin (Leal et al., 2018), and Sauromatum guttatum lectin (Thakur et al., 2017) inhibited by mannose (Table 2).

Structure studies showed Phe, Trp or Tyr mainly formed interaction with mannose. Entadin lectin (Naik et al., 2020) and Genipa americana bark lectin (Costa et al., 2018) were inhibited by lactose sugar. Simple sugar needs higher concentration to inhibits agglutination activity of lectin whereas complex sugar or carbohydrates need lesser concentration (Siritapetawee et al., 2018). Hemagglutination assay is a benchmark to identify lectin from any source and the use of erythrocytes in this assay indicates lectins are specific for different erythrocytes. The lectins from Sambucus ebulus L (Jiménez et al., 2013), Morus alba (white mulberry) (Deepa, et al., 2012), and Tinospora tomentosa (Saha et al., 2014) agglutinate human erythrocytes whereas lectins from, Lonchocarpus campestris seed (De Freitas Pires et al., 2018), Genipa americana bark (Costa et al., 2018), and Coccinia indica fruits (Bobbili et al., 2018) agglutinate rabbit erythrocytes. Lectins from Praecitrullus fistulosus fruit (Shivamadhu et al., 2017), Moringa oleifera seed (Asaduzzaman et al., 2018), Kaempferia rotunda tuberous rhizome (Ahmed et 
al., 2017) and Crotalaria retusa seeds (Aragão et al., 2017) agglutinate human as well as rabbit erythrocytes. Due to diversity of lectin in respect to function and origin its classification is still not completely evolved. Based on the overall structure and carbohydrate-binding site lectin can be divided into four types $\mathrm{i}$. Merolectins: They are low molecular weight proteins consist of only one carbohydrate domain example Hevein, chitin-binding protein from the latex of the rubber tree (Hevea brasiliensis) ii. Hololectins: They contain more than two carbohydrate-binding sites. Hololectins are divalent or multivalent which help to agglutinate cells. Most of the plant lectins belong to this category. iii.
Chimerolectins: They are chimeric proteins composed of carbohydrate-binding domain and catalytic activity domain. Depending upon binding sites they behave as merolectin or hololectin. iv. Superlectins: superlectin can also be considered as chimerolectins consist exclusively of at least two carbohydrate-binding sites, which recognize structurally two unrelated sugars. During the last three decades, advanced biotechnology techniques help to understand the structure and function of various forms of lectin. Based on structural and functional aspects plant lectins are classified into seven different categories (Table 3).

Table 2 Sugar specificity of plant lectin

\begin{tabular}{|c|c|c|}
\hline S.No. & Sugar specificity & Lectin \\
\hline 1 & Mannose & $\begin{array}{c}\text { Lonchocarpus campestris, Diocleinae, Sauromatum guttatum, Pinellia ternata, wheat, Allium sativum, } \\
\text { Microgramma vaccinifolia, Colocasia esculenta, Dioclea lasiophylla mart, Centrolobium microchaete } \\
\text { Mart, Machaerium acutifolium }\end{array}$ \\
\hline 2 & Lactose & $\begin{array}{c}\text { Genipa americana, Spatholobus } \\
\text { Parviflorus, Tinospora tomentosa, Soybean, Trichosanthes anguina, Abrus fruticulosus, Genipa } \\
\text { Americana }\end{array}$ \\
\hline 3 & Galactose & $\begin{array}{c}\text { Nicotiana benthamiana, Bauhinia ungulata L., Lotus corniculatus, Champedak, Euphorbia trigona Miller, } \\
\text { Clathrotropis nitida, Dioclea grandiflora, Morus alba L., Phaseolus lunatus billb, Euphorbia tirucalli, } \\
\text { Euphorbia antiquorum, Artocarpus hypargyreus hance }\end{array}$ \\
\hline 4 & $\begin{array}{l}\text { Glucose and } \\
\text { mannose }\end{array}$ & $\begin{array}{c}\text { Canavalia brasiliensis, Pisum sativum, Dolichos lablab, litchi, Crataeva tapia, Microgramma } \\
\text { vacciniifolia, Parkia platycephala }\end{array}$ \\
\hline 5 & $\begin{array}{c}\text { n-Acetyl } \\
\text { glucosamine }\end{array}$ & $\begin{array}{c}\text { Praecitrullus fistulosus, Apuleia leiocarpa, White kidney bean, Bauhinia forficate, Alpinia purpurata, } \\
\text { Remusatia vivipara, }\end{array}$ \\
\hline 6 & Glycoproteins & Colocasia esculenta, Solanum tuberosum, Lagenaria siceraria, Dypsis decaryi \\
\hline 7 & Arabinose & Anacardium occidentale \\
\hline 8 & D-galactosamine & Phaseolus lunatus L., cicer aritium \\
\hline 9 & Chitin & Cиситis sativus, Moringa oleifera, Praecitrullus fistulosus \\
\hline 10 & Fructose & Moringa oleifera \\
\hline
\end{tabular}

Table 3 Properties and classifications of plant lectins

\begin{tabular}{|c|c|c|c|c|c|c|}
\hline S.No. & $\begin{array}{c}\text { Types of } \\
\text { lectin }\end{array}$ & $\begin{array}{c}\text { First } \\
\text { discovered }\end{array}$ & $\begin{array}{c}\text { Molecular } \\
\text { weight range }\end{array}$ & Plant source & $\begin{array}{c}\text { Sugar } \\
\text { specificity }\end{array}$ & Application \\
\hline 1 & Legume & $\begin{array}{l}\text { Robinia } \\
\text { pseudoacaci } \\
\quad \text { a }\end{array}$ & $20-42 \mathrm{kDa}$ & $\begin{array}{c}\text { Acacia farnesiana, Abrus precatorius, Canavalia ensiformis, } \\
\text { Canavalia } \\
\text { Brasiliensis, Canavalia grandiflora, Canavalia maritime, } \\
\text { Canavalia virosa, Centrolobium microchaete, } \\
\text { Clathrotropis nitida, Cratylia argentea, Calliandra } \\
\text { surinamensis, Dolichos lablab, Dioclea grandiflora, } \\
\text { Dioclea sclerocarpa, Dioclea violacea, Dioclea reflexa, } \\
\text { Dioclea lasiocarpa, Vatairea guianensis, Phaseolus } \\
\text { vulgaris, Phaseolus acutifolius, Phaseolus lunatus L., } \\
\text { Parkia biglobosa, Parkia platycephala, Platypodium } \\
\text { elegans, Cratylia mollis, Cratylia argentea, Centrolobium } \\
\text { tomentosum, Bauhinia ungulata L., Bauhinia forficate, } \\
\text { Bauhinia monandra, Bauhinia variegate, Bauhinia } \\
\text { Purpurea, Spatholobus } \\
\text { Parviflorus, Cicer } \\
\text { arietinum, Lotus, pisum sativum, Dioclea lasiophylla, }\end{array}$ & $\begin{array}{l}\text { D-Galactose, } \\
\text { Lactose, } \\
\text { Methyl } \alpha \text {-D- } \\
\text { galactopyrano } \\
\text { side, mannose, } \\
\text { glucose, }\end{array}$ & $\begin{array}{c}\text { Antibacterial, } \\
\text { Anticancer, Plant } \\
\text { defense, } \\
\text { Vasorelaxant, } \\
\text { Nimeticidal, Seed } \\
\text { germination, } \\
\text { Antifungal, } \\
\text { Amaylase } \\
\text { inhibitor, Anti- } \\
\text { inflamatory, }\end{array}$ \\
\hline 2 & $\begin{array}{l}\text { Chitin- } \\
\text { binding }\end{array}$ & $\begin{array}{l}\text { Solanum } \\
\text { tuberosum }\end{array}$ & $4-70 \mathrm{kDa}$ & $\begin{array}{c}\text { Bauhinia forficate, Microgramma vaccinifolia, Apuleia } \\
\text { leiocarpa, Punica granatum, Moringa oleifera, } \\
\text { Praecitrullus fistulosus }\end{array}$ & $\begin{array}{l}\text { Glycoprotein, } \\
\text { Mannose, } \\
\text { Chitin }\end{array}$ & $\begin{array}{l}\text { Anticancer, } \\
\text { Anticoagulant, } \\
\text { Insecticidal, } \\
\text { Antibacterial, }\end{array}$ \\
\hline 3 & Type-2 RIP & $\begin{array}{c}\text { Ricinus } \\
\text { communis }\end{array}$ & 22-38 kDa & $\begin{array}{c}\text { Sambucus } \\
\text { ebulus L, Abrus fruticulosus, }\end{array}$ & & Toxic, \\
\hline 4 & $\begin{array}{l}\text { Monocot } \\
\text { mannose } \\
\text { specific }\end{array}$ & $\begin{array}{l}\text { Allium } \\
\text { sativum }\end{array}$ & $12-30 \mathrm{kDa}$ & $\begin{array}{c}\text { Pinellia ternate, Triticum aestivum, Hippeastrum, Allium } \\
\text { sativum, Allium chinense, Allium cepa, Colocasia } \\
\text { esculenta, Dioscorea bulbifera }\end{array}$ & mannose & $\begin{array}{l}\text { Anticancer, } \\
\text { Antibacterial, } \\
\text { Insecticidal, } \\
\text { Antifungal, }\end{array}$ \\
\hline 5 & $\begin{array}{l}\text { Jacalin- } \\
\text { related }\end{array}$ & $\begin{array}{l}\text { Maclura } \\
\text { pomifera }\end{array}$ & $\begin{array}{c}\text { Subunits of 2- } \\
14 \mathrm{kDa} \\
\end{array}$ & Jack fruit & $\begin{array}{c}\text { Galagtose/man } \\
\text { nose } \\
\end{array}$ & Anticancer \\
\hline 6 & Amaranthin & $\begin{array}{c}\text { Amaranthus } \\
\text { caudatus }\end{array}$ & $33 \mathrm{kDa}$ & Amaranth & Not reported & Anticancer, \\
\hline 7 & Cucurbitaceae & $\begin{array}{l}\text { Cucurbita } \\
\text { maxima }\end{array}$ & $\begin{array}{l}\text { Subunits of } \\
30-35 \mathrm{kDa}\end{array}$ & $\begin{array}{c}\text { Cucumis sativus, Cucurbita maxima, Trichosanthes } \\
\text { anguina, Cucumis sativus, Lagenaria siceraria, } \\
\text { Praecitrullus fistulosus, Coccinia indica, }\end{array}$ & Lactose, & Plant defence \\
\hline
\end{tabular}

i. Chitin Binding lectins: All the proteins in this category contain one hevein domain for the consideration of chitin-binding lectin. ii. Cucurbitaceae phloem lectins: These lectins are found in phloem exudates of Cucurbita, Citrullus, Cucumis, Sechium, Luffa, and Coccinia species. iii. Monocot mannose-binding lectins: Monocot mannose-binding lectins are extracted and charcterised from monocotyledonous plants. Tuhe first monocot mannose binding lectin was characterized by a snowdrop bulb. iv. Legume lectins: These lectins are isolated from a large family of Leguminosae (Fabaceae). Till now more than 100 lectins are isolated from this family and most of the lectins are purified from seeds (Table 2). v. Type 2 RIP and related lectins: Ribosome-inactivating proteins (RIP) are inhibiting or inactivate eukaryotic ribosomes. RIP is divided in to two category
RIP-I and RIP-II. RIP-II consists of two chain A and B and that having carbohydrate binding sites with lectin activity (Table 2). vi. Jacalin-related lectins: Jacalin is a plant seed tetrameric protein specific to either mannose or galactose sugars. Lectins structurally (Similar domain or fold) and evolutionary related considered as jacalin related lectins. vii. Amaranthin lectin family: Amaranthin lectin was isolated purified from seed of Amaranthus caudate. Amaranthins lectins are homodimeric proteins composed of subunits of approximately $33 \mathrm{kDa}$, which are not glycosylate (Table 3 ). 
Lectin Applications in Biotechnology

\section{Antibacterial Activity}

Since 2012, many of the lectins show inhibitory action against different bacteria, lectin from wheat (Triticum aestivum) was able to increase resistance to the infection of Pseudomonas syringae (Ma et al., 2013). Acacia farnesiana seeds lectin was able to inhibit Xanthomonas axonopodis pv. passiflorae (Gramnegative) and Clavibacter michiganensis (Gram-positive) (Santi-Gadelha et al. 2012). Lectins isolated from stem Tinospora tomentosa showed antibacterial propeties against Salmonella (Saha et al., 2014). Apuleia leiocarpa seeds lectins showed antibacterial activity effects on the gram-positive bacteria $B$. subtilis, $B$. cereus, E. faecalis, M. luteus, S. pyogenes, and $S$. aureus with the smallest MIC $(45.12 \mu \mathrm{g} / \mathrm{ml})$. This lectin also showed inhibition against X.campestris $p v$ campestris, X. campestris pv. viticola, X. campestrispv. malvacearum, Klebsiella pneumoniae, E. coli, P. aeruginosa, and $S$. enteritidis with the lowest minimal inhibition concentration $(11.2 \mu \mathrm{g} / \mathrm{ml})$ against $X$. campestris $p v$. Apuleia leiocarpa lectin was bactericidal (Minimal bactericide concentration of $22.5 \mu \mathrm{g} / \mathrm{ml}$ ) only against the three varieties of $X$. campestris (Carvalho et al., 2015). Over expression of lectin from Arabidopsis shows less disease symptoms after infection with Pseudomonas syringae when it's compare to the wild type of Arabidopsis (Van Hove et al., 2015). Lectin from Bauhinia variegate showed inhibition against oral bacteria facultatively anaerobic, gram-positive Streptococcus mutans and Streptococcus sanguinis (Klafke et al., 2016). Lectins from Canavalia brasiliensis and Cratylia argentea enhanced the antimicrobial immunity of macrophages experimentally infected with S. typhimurium (Silva et al., 2016; Batista et al., 2017). Chitin binding lectin from juicy sarcotesta of Punica granatum showed antibacterial activity against Micrococcus luteus,Serratia marcescens, Streptococcus mutans, Aeromonas sp., Enterococcus faecalis, Escherichia coli, Klebsiella sp., Salmonella enterica serovar. enteritidis, Staphylococcus aureus, Staphylococcus epidermidis and Staphylococcus saprophyticus. It was observed that bacteria treated (Aeromonas sp., S. aureus, $S$ marcescens and S. enterica) with Punica granatum lectin having reduced adhesion and invasion abilities to HeLa cells were reduced when these bacteria were previously treated with ( Silva et al., 2016). Lectin purified and characterized from leaves of Calliandra surinamens showed growth inhibition against Staphylococcus saprophyticus, Staphylococcus aureus (nonresistant) and the Staphylococcus aureus (Oxacillin resistant) whereas against E.coli no inhibition was observed (Figueiredo et al., 2017). Lectin isolated from the latex of Euphorbia tirucalli was able to inhibit the growth of Gram-negative bacteria Escherichia coli (Palharini et al., 2017). The lectin from inflorescence of Alpinia purpurata showed bacteriostatic activity against non-resistant Staphylococcus aureus with minimal inhibitory concentrations (MIC50) of $50 \mu \mathrm{g} / \mathrm{mL}$ and Oxacillin resistant Staphylococcus aureus with minimal inhibitory concentrations (MIC50) of 400 $\mu \mathrm{g} / \mathrm{mL}$. It also showed bactericidal effect on the non-resistant Staphylococcus aureus with minimal bactericidal concentrations (MBC50) of $200 \mu \mathrm{g} / \mathrm{mL}$ (Ferreira et al., 2018). The lectin isolated from the crude latex of Euphorbia antiquorum L. can inhibits the growth of Gram-positive bacteria such as Staphylococcus aureus and Staphylococcus epidermidis, without killing them with a minimum inhibitory concentration (MIC) of $2000 \mu \mathrm{g} / \mathrm{ml}$, Propionibacterium acnes (human skin commensal) with MIC of $125 \mu \mathrm{g} / \mathrm{ml}$ and Streptococcus agalactiae with MIC of $250 \mu \mathrm{g} / \mathrm{ml}$. Whereas in case of gram negative bacteria Samonella typhimurium which inhibits with a MIC of $1000 \mu \mathrm{g} / \mathrm{ml}$. (Siritapetawee et al., 2018) (Table 4)

Table 4 Antibacterial activity of plant lectins

\begin{tabular}{|c|c|c|}
\hline Plants & Source & Against Bacteria \\
\hline Triticum aestivum & Seed & Pseudomonas syringae \\
\hline Acacia farnesiana & Seed & Xanthomonas axonopodis pv. passiflorae and Clavibacter michiganensis \\
\hline $\begin{array}{l}\text { Tinospora } \\
\text { tomentosa }\end{array}$ & Stem & Salmonella \\
\hline Apuleia leiocarpa & Seed & $\begin{array}{c}\text { B. subtilis, B. cereus, E. faecalis, } M \text {. luteus, } S . \text { pyogenes, and } S . \text { aureus, } X . \text { campestris pv. } \\
\text { campestris, X. campestris pv. viticola, X. campestris pv. malvacearum, Klebsiella } \\
\text { pneumoniae, E. coli, } P \text {. aeruginosa, and } S . \text { enteritidis }\end{array}$ \\
\hline Bauhinia variegate & Seed & Streptococcus mutans and Streptococcus sanguinis \\
\hline $\begin{array}{l}\text { Canavalia } \\
\text { brasiliensis }\end{array}$ & Seed & S. typhimurium \\
\hline Cratylia argentea & Seed & S. typhimurium \\
\hline Punica granatum & Fruit & $\begin{array}{l}\text { Micrococcus luteus, Serratia marcescens, Streptococcus, Aeromonas sp., Enterococcus } \\
\text { faecalis, Escherichia coli, Klebsiella } \mathrm{sp} \text {., Salmonella enterica serovar. Enteritidis, } \\
\text { Staphylococcus aureus, Staphylococcus epidermidis and Staphylococcus saprophyticus. }\end{array}$ \\
\hline $\begin{array}{l}\text { Calliandra } \\
\text { surinamensis }\end{array}$ & Leaf & Staphylococcus saprophyticus, Staphylococcus aureus and the Staphylococcus aureus \\
\hline Euphorbia tirucalli & Latex & Escherichia coli \\
\hline Alpinia purpurata & Inflorescence & Staphylococcus aureus \\
\hline $\begin{array}{l}\text { Euphorbia } \\
\text { antiquorum L. }\end{array}$ & Latex & Staphylococcus aureus and Staphylococcus epidermidis \\
\hline
\end{tabular}

\section{Anti-Bio-Film Activity}

A Lectin from litchi (Litchi chinensis) seeds showed antibiofilm activity against Pseudomonus aeruginosa (Bose et al., 2016). Lectin isolated from the leaves of Calliandra surinamensis is an effective inhibitor of oral multispecies biofilms formed by bacteria from supragingival plaque (Figueiredo et al., 2017). Chitin binding lectin isolation and purified from pomegranate (Punica granatum) sarcotesta showed significant antibiofilm activity on Candida albicans (pathogenic yeast) at inhibitory concentrations of 0.195 and $0.39 \mu \mathrm{g} / \mathrm{mL}$ (Da Silva et al., 2018) The lectin remarkably inhibited biofilm formation by non-resistant Staphylococcus aureus isolate and Candida albicans from inflorescence of Alpinia purpurata at sub-inhibitory concentrations (Ferreira et al., 2018). Bauhinia variegata lectin showed anti-biofilm formation against Streptococcus mutans and S. sanguinis (Klafke et al., 2016).

\section{Antifungal Activity}

Chitin binding lectins are predominant in plants that bind to fungal cell wall which is made of chitin a complex polysaccharide. CBL lectins bind to chitin and stop the growth of fungus. Galctose binding lectin isolated from seeds of Bauhinia ungulata L. (Caesalpinoideae) showed antifungal activity against Fusarium solani, Fusarium moniliforme, Fusarium oxysporum, Colletotrichm lindemuthianum and Aspergillus niger (Silva et al., 2014). Lectin isolated and characterized from seed of Spatholobus parviflorus showed anti-fungal activity against Aspergillus niger and Fusarium sp. Aspergillus niger hyphal growth inhibition was seen at low concentration approx. $0.04 \mathrm{mg} / \mathrm{mL}$ of lectin. Whereas Fusarium sp. was inhibited at much higher lectin concentration (Geethanandan et al., 2013). The lectin from Phaseolus vulgaris cv. Chinese pinto bean showed antifungal activity against mycelial growth in Valsa mali a destructive fungus of apple, by $30.6 \%$ at $30 \mu \mathrm{M}$ (Ang et al., 2014). The crude plant lectin isolated from the stem of Tinospora tomentosa shows fungal growth inhibition of Aspergillus niger and showed a clear inhibition of the growth of another fungal strains saccharomyces cerevasecis (Saha et al., 2014). Lectin isolated from leaf Allium sativum showed antifungal activity its gene was further expressed in an elite indica rice cv. IR64 by employing Agrobacterium tumefaciens-mediated transformation to engineer rice plants conferring resistance to sheath blight which mainly caused by Rhizoctonia solan (plant pathogenic fungus) (Ghosh et al., 2016). Lectin isolated from Phaseolus lunatus billb seeds inhbited the fungal growth of Sclerotium rolfsii, Fusarium solani, Fusarium oxysporum, and Botrytis cinerea (Wu et al., 2016). Calliandra surinamensis leaf lectin was assessed against four Candida species but only Candida kruse $i$ was sensitive to this lectin with MIC 125 $\mu \mathrm{g} / \mathrm{mL}$ and MFC of $250 \mu \mathrm{g} / \mathrm{mL}$ (Figueiredo et al., 2017). The lectin from Sunflower seeds (Helianthus annuus L.) affects the viability of sunflower phytopathogenic fungus Sclerotinia sclerotiorum (Del Rio et al., 2018). The pomegranate (Punica granatum) sarcotesta contains a chitin-binding lectin showed antifungal activity against Candida albicans and Candida kruse with MIC50 of 25.0 and $12.5 \mu \mathrm{g} / \mathrm{mL}$ respectively (Da Silva et $\boldsymbol{a l}$., 2018). The lectin from inflorescence of Alpinia purpurata showed fungistatic activity against Candida albicans and Candida parapsilosis (Ferreira et al., 2018). Antifungal protein from Cicer arietinum seeds showed antifungal activity against Candida parapsilosis, Candida krusei, and Candida tropicalis (Kumar et al., 2014) (Table 5). 
Table 5 Antifungal activity of plant lectins

\begin{tabular}{|c|c|c|}
\hline Plants & Source & Against fungus \\
\hline Bauhinia ungulata $\mathrm{L}$ & Seed & $\begin{array}{c}\text { Fusarium solani, Fusarium moniliforme, Fusarium oxysporum, Colletotrichm lindemuthianum } \\
\text { and Aspergillus niger }\end{array}$ \\
\hline Spatholobus parviflorus & Seed & Aspergillus niger and Fusarium sp. \\
\hline Phaseolus vulgaris $\mathrm{cv}$ & Seed & Valsa mali \\
\hline Tinospora tomentosa & Stem & Aspergillus niger and Accharomyces cerevasecis \\
\hline Allium sativum & Leaf & Rhizoctonia solani \\
\hline Phaseolus lunatus billb & Seed & Sclerotium rolfsii, Fusarium solani, Fusarium oxysporum, and Botrytis cinerea \\
\hline $\begin{array}{l}\text { Calliandra } \\
\text { surinamensis }\end{array}$ & Leaf & Candida krusei \\
\hline Helianthus annuus L. & Seed & Sclerotinia sclerotiorum \\
\hline Punica granatum & Fruit & Candida albicans and Candida kruse \\
\hline Alpinia purpurata & Inflorescence & Candida albicans and Candida parapsilosis \\
\hline Cicer arietinum & Seed & Candida parapsilosis, Candida krusei, and Candida tropicalis \\
\hline
\end{tabular}

\section{Insecticidal Activity}

Hippeastrum hybrid (Amaryllis) ornamental plant bulb lectin showed insecticidal activity against the larvae of the cotton leaf worm (Spodoptera littoralis) (Caccia et al., 2012). Tubers of Colocasia esculenta having lectin which is toxic against Aphis gossypii (Cowpea aphid), Dysdercus cingulatus (Red cotton bug) and Aphis craccivora (Cowpea aphid) with the lectin concentration of $9.98 \pm 0.239 \mu \mathrm{g} / \mathrm{mL}$, $16.95 \pm 0.279 \mu \mathrm{g} / \mathrm{mL}$ and $15.21 \pm 0.274 \mu \mathrm{g} / \mathrm{mL}$ respectively (Das et al., 2013) Microgramma vaccinifolia rhizome lectin showed toxicity against Nasutitermes corniger (termite) workers and soldiers and acts as termiticidal lectin (Albuquerque et al., 2014). The lectin of Myracrodruon urundeuva and its leaf extract showed insecticidal properties against Sitophilus zeamais (maize weevil) which is a major pest of maize (Camaroti et al., 2013). The effects of Dioclea violacea lectin (DVL) on larval development in flour moth or mill moth (Anagasta kuehniella). DVL interfered with larval growth, retarding development and decreasing larval mass without affecting survival (Oliveira et al., 2015). Lectin with insecticidal property against the stored product pest, Callosobruchus maculatus was successfully isolated from the seeds of Canavalia virosa (Shanmugavel et al., 2016). Moringa oleifera seed cake lectin exerted deleterious effects on larvae (LC50: $0.89 \mathrm{mg} / \mathrm{mL}$ ) and eggs (EC50: $0.14 \mathrm{mg} / \mathrm{mL}$ ) of Aedes aegypti (Yellow fever mosquito) and served as an oviposition-stimulant at the concentration of $0.1 \mathrm{mg} / \mathrm{mL}$ (De Oliveira et al., 2016). The chitin-binding lectin from Moringa oleifera seeds showed insecticidal activity against Anagasta kuehniella (flour moth) (Fernando et al., 2017). Later the same chitin-binding lectin from Moringa oleifera seeds were investigated on gamma irradiation a low dose of gamma irradiation ( $10 \mathrm{mGy}$ ) can be used to improve the deleterious effects of moringa seed lectin on Aedes aegypti larvae and eggs (Santos et al., 2018) Lectin from Abelmoschus esculentus seeds Kunitz-type serine/cysteine protease inhibitor reported its toxic effects on the Mediterranean fruit fly Ceratitis capitata (De Lacerda et al., 2017). Lectin extracted from Polygonum persicaria L. is able to decrease damages of lepidopterous pests mainly $H$. armigera and $P$. brassicae on agricultural field (Rahimi et al., 2018). The lectin isolated from the leaves of Schinus terebinthifolius showed insecticidal activity against maize weevi (Sitophilus zeamais). The lectin doses of 100, 200, and $250 \mathrm{mg} / \mathrm{g}$ showed mortality rates of $32 \%, 40 \%$, and $51 \%$ respectively on $7^{\text {th }}$ day of treatments. On $12^{\text {th }}$ day, the percentage of dead insects were increased to $94 \%$ to $97 \%$. On $20^{\text {th }}$ day of treatment all the insects were died, Whereas in control groups all the insects were survived even on $34^{\text {th }}$ day (Camaroti et al., 2018) (Table 6).

Table 6 Insecticidal activity of plant lectins

\begin{tabular}{|c|c|c|}
\hline Plants & Source & Against insects \\
\hline Hippeastrum hybrid & Bulb & Cotton leaf worm \\
\hline Colocasia esculenta & Tuber & Cowpea aphid and Red cotton bug \\
\hline Microgramma vaccinifolia & Rhizome & Termite \\
\hline Myracrodruon urundeuva & Leaf & Maize weevil \\
\hline Dioclea violacea & Seed & Flour moth \\
\hline Canavalia virosa & Seed & Cowpea weevil \\
\hline Moringa oleifera & Seed & $\begin{array}{c}\begin{array}{c}\text { Yellow fever mosquito and flour } \\
\text { moth }\end{array} \\
\text {. }\end{array}$ \\
\hline Abelmoschus esculentus & Seed & Mediterranean fruit fly \\
\hline Polygonum persicaria $L$. & Fruit & Cotton bollworm \\
\hline Schinus terebinthifolius & Leaf & Maize weevil \\
\hline
\end{tabular}

\section{Anti-HIV Activity}

Dioscorea bulbifera bulbils lectin showed anti-HIV activity and inhibits the HIV1 reverse transcriptase activity in a dose dependent manner with IC50 of $1.3 \mu \mathrm{g}$ (Sharma et al., 2017).Sauromatum guttatum (Sauromatum venosum) plant tuber lectinglycan array analysis and in-silico studies of the coding sequence proposed biological property as a putative anti-HIV agent (Thakur et al., 2017).

\section{Antileishmanial Activity}

Lectinn isolated from Abrus fruticulosus seeds that has type 2 ribosomeinactivating properties showed antileishmanial activity against the promastigote form of Leishmania (Vasconcelos et al., 2018).

\section{Nematicidal Activity}

The lectin from white kidney beans (Phaseolus vulgaris) showed nematicida effect against Teladorsagia circumcincta and Trichostrongylus colubriformis which are the parasites of sheep and goats (Ríos-de Álvarez et al., 2012). Seeds of Dioclea lasiophylla having lectin which shows less toxicity against Artemia sp. nauplii (Pinto et al., 2013). Lectin isolated from Moringa oleifera seed was evaluated for the inhibition of nematodes Strongyloides genera, Oesophagostomum, Haemonchus and Trichostrongylus in vitro effect of WSMoL (water soluble Moringa oleifera lectin) on hatching of eggs and the development of early-stage larvae of gastrointestinal nematodes from naturally infected goats (De Medeiros et al., 2018). Lectin from Abelmoschus esculentus seeds Kunitztype serine/cysteine protease inhibitor reported its toxic effects on the root-knot nematodes Meloidogyne incognita and Meloidogyne javanica (De Lacerda et al., 2017). Eutirucallin: lectin isolated from latex of Euphorbia tirucalli was shows to be effective when tested directly against Toxoplasma gondii infection in vitro (Palharini et al., 2017). Canavalia brasiliensis lectin inhibits Haemonchus contortus also known as the barber's pole worm, in vitro, and through the in silico studies suggested that the inhibition of development is directly related to the recognition of the core trimannoside present in the $\mathrm{N}$-glycans of these parasites (Batista et al., 2018)

\section{Lectin application in the therapeutic aspect}

\section{Anticancerous Activity}

Canavalia ensiformis (ConA) and Canavalia brasiliensis (ConBr) lectins showed antiproliferative activity with the IC50 values of approximately $3 \mu \mathrm{g} / \mathrm{mL}$ and 20 $\mu \mathrm{g} / \mathrm{mL}$ using human leukemia MOLT-4 and HL-60 after $72 \mathrm{hrs}$ of incubation with the lectins. The lectin was not toxic against normal human peripheral blood lymphocytes even with $200 \mu \mathrm{g} / \mathrm{mL}$ concentration of lectins (Faheina-Martins $\boldsymbol{e t}$ al., 2012). Hog plum (Ximenia Americana) fruit kernels is having a lectin known as Riproximin is specifically bind to two types of glycostructures, the $\mathrm{N}$-linked

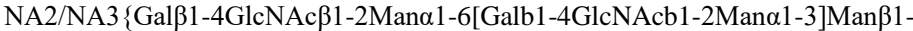
4GlcNAcBSA/Galß1-4GlcNAc/1-2Mano1-6[Galb1-4GlcNAcb1-2(Galb1-

4GlcNAcb1-2)Mano1-3]Man 1 1-4GlcNAc-BSA $\}$ and the O-linked clustered Tn tumor-specific antigen which found in tumor cells (Bayer et al., 2012). Lectin isolated and characterized from mulberry leaf induced apoptosis in human breast cancer cell line (MCF-7) and colon cancer cell line (HCT-15). Lectin required with the concentration of $8.5 \mu \mathrm{g} / \mathrm{mL}$ for MCF-7 and $16 \mu \mathrm{g} / \mathrm{mL}$ for HCT-15 to get $50 \%$ inhibition of cell growth after $24 \mathrm{hrs}$ induced with lectin ((Deepa and Priya, 2012; Deepa et al., 2012). Lectin isolated from Bauhinia ungulata L. seeds showed in vitro antiproliferative activity against the HT-29 cell line of human colon adenocarcinoma in a dose-dependent manner, which require $160 \mu \mathrm{g} / \mathrm{mL}$ concentration of lectin to inhibit $80 \%$ of cell growth after 24 hrs of incubation (Silva et al., 2014). Lectin from pods of Lotus corniculatus showed antiproliferative activity towards human leukemic (THP-1) cancer cells and lung cancer (HOP62) cells and colon cancer cells (HCT116) with an IC50 of $39 \mu \mathrm{g} / \mathrm{mL}$ and 50 $\mu \mathrm{g} / \mathrm{mL}$ and $60 \mu \mathrm{g} / \mathrm{mL}$ respectively after $24 \mathrm{hrs}$ of lectin dose (Rafiq et al., 2013) Pea (Pisum sativum L.) seeds lectin was able to inhibit $84 \%$ of Ehrlich ascites carcinoma (EAC) cells after $24 \mathrm{hrs}$ of incubation with the concentration of 120 $\mu \mathrm{g} / \mathrm{mL}$ of pea lectin (Kabir et al., 2013). The seeds of Phaseolus vulgaris cv. Chinese pinto bean showed anti proliferative activity against nasopharyngeal carcinoma HONE-1 cells with an IC50 of $1 \mathrm{mg} / \mathrm{mL}$ after $24 \mathrm{hrs}$ of incubation with lectin (Ang et al., 2014). Monocot mannose-binding lectin from tubers of Pinellia ternata showed anti-proliferative effects on human liver tumor cell line Bel-7404 (Zhou et al., 2014). Lectin from the bulbs of Allium chinense inhibited $50 \%$ of the 
human hepatoma Hep-3B cells after 48 hrs with the doses of $60 \mu \mathrm{g} / \mathrm{mL}$ of allium lectin (Xiao et al., 2015). Lectin extracted from the seeds of Canavalia brasiliensis $(\mathrm{ConBr})$ as a therapeutic agent for melanoma because it inhibit the growth of murine melanoma B16F10 cells (Silva et al., 2014). Bauhinia forficata seeds lectin was treated against the breast cancer cells MCF-7, MDA-MB-231, MDA-MB-468 and MCF-10A among of all these cells Bauhinia forficate lectin was effective against MCF-7 cells (Silva et al., 2014). Antiproliferative lectin from Cicer arietinum seeds was toxic against human oral carcinoma cells (KB) at the concentration of $37.5 \mu \mathrm{g} / \mathrm{mL}$ (IC50) after $48 \mathrm{hrs}$ of incubation and at the same time it was not toxic for normal human peripheral blood mononuclear cells (PBMCs) (Kumar et al., 2014). Toxic effects of Microgramma vacciniifolia rhizome lectin on lung mucoepidermoid carcinoma (NCI-H292) cells at IC50 concentration of $25.23 \mu \mathrm{g} / \mathrm{mL}$, It did not affect the viability of chronic myelocytic leukaemia K562 and larynx epidermoid carcinoma Hep-2 tumour cells, as well as PBMCs normal cells (Albuquerque et al., 2014). Mannose-binding Polygonatum odoratum lectin showed anti-proliferative effect on MCF-7 cell growth with IC50 concentration of $10 \mu \mathrm{g} / \mathrm{mL}$ after $24 \mathrm{hrs}$ of inhibition (Ouyang et al., 2014). Lectin isolated from soybean seed showed invitro antitumor effect on HeLa (cervical cancer), Hep2 (oral cancer), HepG2 (liver cancer), MDAMB 231(breast cancer), U373 MG (glioblastoma) with the IC50 concentration of $60,20,40,40,51 \mu \mathrm{g} / \mathrm{mL}$, respectively and it did not affect the $\mathrm{HaCaT}$ (human keratinocyte). It also showed invivo antitumor effect on Dalton's lymphoma (DL) bearing mice; There was $74 \%$ and $82 \%$ reduction in cancer cell survival on the $10^{\text {th }}$ day for the 1 and $2 \mathrm{mg} / \mathrm{kg}$ body weight doses, respectively (Panda et al., 2014). Amaranthus mantegazzianus seed lectin and commercial Amaranthus caudatus lectin were capable of inhibiting UMR106 rat osteosarcoma-derived cell proliferation with an IC50 of $0.1 \mathrm{mg} / \mathrm{mL}$ and $0.08 \mathrm{mg} / \mathrm{mL}$ respectively after $24 \mathrm{hrs}$ of incubation (Quiroga et al., 2015) Typhonium flagelliforme (Lodd.) blume having lectin in tuber reported as antiproliferation activity against human breast cancer cell MCF-7 with LC50 of $90.78 \mathrm{ppm}$ and the same tuber was isolated from other region showing LC50 of 130.93 ppm (Biosci et al., 2015). Ribosome-inactivating protein; three types of lectin ETRI1, ETRI2 and ETRI3 from the latex of Euphorbia trigona miller showed cytotoxicity against tumoral cell lines HeLa (IC50-11nM, 12nM, 10nM respectively), A549 (IC50-32nM, 32nM, 38nM respectively), H116 (IC50-40nM, $18 \mathrm{nM}, 21 \mathrm{nM}$ respectively), HL-60 (IC50-75nM, 44nM, 44nM respectively), HT29 (no inhibition) and non-tumoral cell line NIH-3T3 (IC50-875nM, 480nM 480nM respectively) analyzed by flowcytometry (Villanueva et al., 2015). Highmannose-type glycans of Maackia Amurensis lectin was purchased which is known to interact with the $\alpha 2,3$-sialic acid moiety expressed on the MCF-7 human breast cancer cell line. The researcher groups have deglycosylated the lectin by using PNGase F for the removal of the high-Man-type N-linked glycans which leaving the two paucimannosidic type glycans in place on deglycosylated lectin, structural analysis of both the lectin releave the information that there was no difference in both the structure and both the lectin were active. They found that the presence of a single GlcNAc attached to Asn 61 is sufficient for the lectin activity (Kim et al., 2015). Polygonatum odoratum lectin induce apoptosis and autophagy in lung cancer A549 cells. They found that the lectin down-regulated the expression of micro RNA (miR-1290) and at the same time upregulated the expression of micro RNA (miR-15a-3p), which leads to the apoptosis and autophagy of A549 cells by ROS-p53 mediated pathway (Wu et al., 2016). White kidney bean (Phaseolus vulgaris $c v$.) seeds lectin showed anti-proliferative activity on HONE1 cells, HepG2 cells, MCF7 cells and WRL68 cells with IC50 values of $18.8 \mu \mathrm{M}, 19.7 \mu \mathrm{M}, 26.9$ $\mu \mathrm{M}$, and $>80 \mu \mathrm{M}$ respectively for a $48 \mathrm{hrs}$ treatment with lectin (Chan et al., 2016). Brazilian lima bean variety (Phaseolus lunatus L. var. cascavel) seeds having lectin with anti-tumor activity against melanoma derived cells (A375) at doses of 100,50 and $25 \mu \mathrm{g} / \mathrm{mL}$, reducing tumor cells after $48 \mathrm{hrs}$ of incubation number of cells was reduced by 73,41 , and $7 \%$, and after $72 \mathrm{hrs}$ of incubation it was reduced by 83,53 , and $0 \%$, respectively (Lacerda $\boldsymbol{e t}$ al., 2016). Lectin from Canavalia virosa seeds having cytoxicity activity against rat glioma cells (C6). The researcher group found that $100 \mu \mathrm{g} / \mathrm{mL}$ of lectin can able to decrease the cell viability by $25 \%$ and 50\% after 24 and $48 \mathrm{hrs}$ of treatment with lectin, respectively (Osterne $\boldsymbol{e t} \boldsymbol{a l}$., 2017). Lectin from the latex of mulberry (Morus indica) showed toxicity against an epithelial cell line MDCK and a breast cancer cell line MCF-7 cell line at the concentration of $0.625 \mu \mathrm{M}$ of lectin for $72 \mathrm{hrs}$ of treatment the viability for both cell lines reached $\sim 35 \%$ and at the concentration of $1.25 \mu \mathrm{M}$ it reached $17 \%$ in case of MDCK cells and 26\% in case of MCF-7 (Datta et al., 2016). Lectin from latex of Lagenaria siceraria showed invitro cell cytotoxicity against MCF-7, A549, Dalton's lymphoma ascites (DLA), and Ehrlich ascites carcinoma (EAC) with IC 50 value of $17.4 \mu \mathrm{g} / \mathrm{mL}, 20.4 \mu \mathrm{g} / \mathrm{mL}, 12 \mu \mathrm{g} / \mathrm{mL}$, and $19.5 \mu \mathrm{g} / \mathrm{mL}$, after $48 \mathrm{hrs}$ of lectin doses but in case of non- cancerous cells NIH-3T3 was not showed toxicity at $50 \mu \mathrm{g} / \mathrm{mL}$. It also showed invivo antitumor activity in ascites tumor model, Six dose of lectin with the concentration of $25 \mathrm{mg} / \mathrm{kg}$ was administered to tumor bearing mice on every alternative days and the found that there were reduction in the size of tumor (Vigneshwaran et al., 2016). Phaseolus lunatus billb seed lectin strongly inhibit the prolif-eration of K562 leukemia cells with an IC50 of $13.7 \mu \mathrm{M}$, whereas HeLa and HepG2 cells were only weakly affected after $48 \mathrm{hrs}$ of incubation with the lectin (Wu et al., 2016). Calliandra surinamensis leaf lectin was evaluated for cell cytotoxicity on the cancer cell lines K562 (chronic myelogenous leukemia) and T47D (breast cancer) and noncancerous cells human peripheral blood mononuclear (PBMCs) after the treatment of lectin for $72 \mathrm{hrs}$ the
IC50 observed with the concentration of $67.04 \pm 5.78$ and $58.75 \pm 2.5 \mu \mathrm{g} / \mathrm{mL}$ for cancerous cells respectively. Lectin did not affect non-cancerous cells at concentrations lower than $100 \mu \mathrm{g} / \mathrm{mL}$ (Figueiredo et al., 2017). The concanavalin A (Con A) and jacalin lectins on colonic adenocarcinoma cells (SW480) evaluated for antiproliferation of cells with pre-incubated lectins with dairy propionibacteria (Propionibacterium acidipropionici CRL 1198) as well as post-incubated lectins with the $P$. acidipropionici CRL 1198. They found that there were decreased in the antiproliferation activity of SW480 cells after incubating lectins with $P$ acidipropionici CRL 1198 as compare to the lectins activity before incubating the lectins with P. acidipropionici CRL 1198 (Zarate, 2017). Lectin from Dioscorea bulbifera bulbils inhibit the cell growth of HT 29, SW 620 and HepG2 cells with IC50 of $110 \mu \mathrm{g}, 9.8 \mu \mathrm{g}, 40 \mu \mathrm{g}$ respectively after $72 \mathrm{hrs}$ of interaction with lectin (Sharma et al., 2017). The seeds of Canavalia bonariensis lectin showed antitumor activity against rat $\mathrm{C} 6$ glioma cells with the lectin concentration of 50 and $100 \mathrm{mg} / \mathrm{mL}$ decrease cell viability at $40 \%$ and $50 \%$, respectively, after $24 \mathrm{hrs}$ treatment where as in case of $48 \mathrm{hrs}$ of treatment with lectin concentration of 30 and $100 \mathrm{mg} / \mathrm{mL}$ cell viability decreased upto $30 \%$ and $50 \%$ respectively (Cavada et al., 2018). Native as well as recombinant lectin of Cratylia mollis seed showed toxicity against human prostate adenocarcinoma (PC-3) cells after 24 hrs exposure to the lectin along with the Concanavalin A. They observed that there were more than $10 \%$ decreased in the cell viability at $100 \mu \mathrm{g} / \mathrm{mL}$ and $300 \mu \mathrm{g} / \mathrm{mL}$ of lectin concentration in case of both the native as well as recombinant Cratylia mollis seed lectin; IC50 were $29.91 \mu \mathrm{g} / \mathrm{mL}$ and $39.69 \mu \mathrm{g} / \mathrm{mL}$ for recombinant and native Cratylia mollis seed lectin respectively. But there were no significant decrease in the cell viability in case of Concanavalin A with the concentration of 30 to 300 $\mu \mathrm{g} / \mathrm{mL}$ (Figueirôa et al., 2017). Lectins isolated from the seeds of Canavalia brasiliensis, Canavalia maritima, Dioclea lasiocarpa and Dioclea sclerocarpa showed anti-proliferative activity against Human ovarian carcinoma (A2780), human Caucasian lung carcinoma (A549), human prostate carcinoma (PC3) and human breast carcinoma (MCF-7), with IC50 values ranging from 52 to $529 \mathrm{nM}$ Out of the four different lectins, Dioclea lasiocarpa lectin showed highly active against A2780 with IC50 value of $52 \pm 2 \mathrm{nM}$. Whereas with MCF-7 IC50 value was $275 \mathrm{nM}$ (Gondim et al., 2017). Later on the same group of researcher worked on the same lectin (Dioclea lasiocarpa lectin) showed decrease in the cell viability of rat glioma cells (C6) but decrease in the cell viability starts at the low concentration $10 \mu \mathrm{g} / \mathrm{mL}$ both after $24 \mathrm{hrs}$ and $48 \mathrm{hrs}$ on incubation (Nascimento et al., 2017). Methyl- $\beta$-d-galactopyranoside specific lectin from Kaempferia rotunda showed $43.7 \%$ cell growth inhibition in vitro against EAC cells at 160 $\mu \mathrm{g} / \mathrm{mL}$ at the same time it was not inhibited the growth of U87 cell line and in-vivo antitumor effect of the lectin was observed in EAC bearing Swiss albino mice a the doses of 3.0 and $6.0 \mathrm{mg} / \mathrm{kg} / \mathrm{day}$ for five consecutive days and found that there were decrease in cell growth of EAC by 41 and 59\% respectively (Ahmed $\boldsymbol{e t}$ al., 2017). The crude lectin from the latex of Euphorbia tirucalli showed toxicity against non-tumor cell lines such as peritoneal macrophages, murine bonemarrow-derived macrophages and fibroblasts after $18 \mathrm{hrs}$ of incubation but purified lectin did not showed toxicity against these non-tumor cells. Where as in case of tumor cell lines HeLa: Human cervical cancer cell line, PC-3: Human prostate cancer cell line, MDA-MB-231: Human breast cancer cell line, MCF-7: Human breast adenocarcinoma cell line the crude and purified lectin showed antiproliferative activity; at concentration of 25 and $50 \mu \mathrm{g} / \mathrm{mL}$, HeLa and PC3 were more susceptible to the harmful effects of purified lectin. MDA-MB-231 and MCF-7 were more susceptible to the harmful effects of crude lectin. There was same effect even at higher concentration. Breast cancer cell lines (MDA-MD-231 and MCF-7) were more sensitive to crude extract (47.9 and 56.9\% death rates) than to the purified lectin (25.5 and 32.5\%) death rates. Meanwhile, purified lectin killed more PC 3 cells ( $27.5 \%$ death rate) than crude extract (19.6\% death rate). There was no difference in cytotoxicity in HeLa cells between crude extract and purified lectin. In-vivo antitumor activities of both the crude and purified lectin were evaluated on intraperitoneal administered 100 Ehrlich ascites carcinomas (EAC) on mice. They found that the mice treated with crude and purified lectin were survived and there were no significant difference between the survival rates (Palharini et al., 2017). In vitro cytotoxic effects of Moringa oleifera seeds lectin on (B16-F10) melanoma cells; concentration of lectin ranging from 1.5-16 $\mu \mathrm{M}$ was evaluated for the reduction of the cells. The IC50 value was found at $9.72 \mu \mathrm{M}$ They determine that the reduction of the number of cells is due to the activation of caspases 3, 8 and 9 (Luz et al., 2017). Lectin from the same Moringa oleifera seeds inhibit the growth of Ehrlich ascites carcinoma (EAC) cell in-vitro with a concentration of lectin ranging from $25-200 \mu \mathrm{g} / \mathrm{mL}$; at $200 \mu \mathrm{g} / \mathrm{mL}$ and $12.5 \mu \mathrm{g} / \mathrm{mL}$ the inhibitory effect was $71.08 \%$ and $15.27 \%$ respectively. In-vivo antitumor effect of the Moringa oleifera lectin on Ehrlich ascites carcinoma (EAC) on mice was observed at a concentration of lectin dose of $2.0 \mathrm{mg} / \mathrm{kg} /$ day there were $25.38 \%$ of EAC cell growth inhibition but when the concentration was increased to 4.0 $\mathrm{mg} / \mathrm{kg} / \mathrm{day}$, the growth inhibition was increased to 55\% (Asaduzzaman et al., 2018). Lectin from the phloem exudates/sap of fruit of Praecitrullus fistulosus showed invitro antiproliferative effects on cell lines HT29 (colon cancer), HeLa (cervical cancer), MCF7 (breast cancer) and K562 (leukemia) with an IC50 value of $43.80 \mu \mathrm{g}, 45.17 \mu \mathrm{g}, 62.80 \mu \mathrm{g}$ and $76.23 \mu \mathrm{g}$ respectively. The lectin did not showed cytotoxicity against normal cell line, peripheral blood mononuclear cells (PBMCs) even at a higher concentration of $1 \mathrm{mg} / \mathrm{mL}$. In-vivo anticancerous activity was observed on EAC model $10 \mathrm{mg} / \mathrm{kg}$ injection for every alternate day (3 
doses on day 7, $9 \& 11$ ). When compare it to the control i.e., without injection of lectin; the mice after receiving the first dose itself on day 7 there were gradual decrease in the body weight. After receiving the $3^{\text {rd }}$ dose mice reduced tumor cell proliferation up to $75 \%$ (Shivamadhu et al., 2017). High mannose N-glycan binding lectin from Remusatia vivipara tubers showed anticancerous activity against the human breast cancer cell lines MDA-MB-468, MCF-7 and MCF-10A After $48 \mathrm{hrs}$ of treatment of lectin; $67.07 \%$ and $34.23 \%$ of cell viability was decreased in MDA-MB-468 and MCF-7 cells at $10 \mu \mathrm{g} / \mathrm{mL}$ dose of lectin. Whereas at $100 \mu \mathrm{g} / \mathrm{mL}$ concentration the cell viability decrease was $80.8 \%$ and $50.6 \%$ respectively. In case of non-tumorigenic MCF-10A cells derived from human fibrocystic mammary tissue, lectin exerted only marginal effect with $18.2 \%$ decrease in cell viability at $40 \mu \mathrm{g} / \mathrm{mL}$ concentration of lectin (Sindhura et al. 2017). Lectin from Dioclea lasiophylla Mart. Ex Benth seeds showed toxicity against C6 glioma cells at a concentration of 50 and $100 \mu \mathrm{g} / \mathrm{mL}$ of lectin decreased cell viability after $24 \mathrm{hrs}$ of incubation and at $30-100 \mu \mathrm{g} / \mathrm{mL}$ after $48 \mathrm{hrs}$ incubation (Leal et al., 2018). Canavalia ensiformis (ConA) and Dioclea violacea (DVL) lectins showed antiglioma effect on rat glioma cells (C6). Dioclea violacea lectin at concentration of $30 \mu \mathrm{g} / \mathrm{mL}$ decreased cell viability around $30 \%$ after $24 \mathrm{hrs}$ of incubation, whereas after $48 \mathrm{hrs}$ of incubation there were $66 \%$ of decrease in cell viability. Canavalia ensiformis lectin at concentration of $30 \mu \mathrm{g} / \mathrm{mL}$ the decrease in the cell viability was observed only after 24 hrs of incubation, there were only $30 \%$ decrease in the cell viability after $48 \mathrm{hrs}$ of incubation (Nascimento et al., 2018) Pisum sativum seeds lectin showed inhibition of 17, 35 and $63 \%$ in SW480 cells at concentration of $0.25,0.5$ and $1.0 \mathrm{mg} / \mathrm{mL}$ after 3 days of treatment. Similarly, 18,36 and $62 \%$ cell growth inhibition were noted in SW48 cells at concentration of $0.25,0.5$ and $1.0 \mathrm{mg} / \mathrm{mL}$ (Islam et al., 2018). The purified lectin from soya bean seeds displayed minor inhibition with $30 \%$ cell growth inhibition of B16F1 melanoma cells at a concentration of $35 \mu \mathrm{g} / \mathrm{mL}$ (Roy et al., 2018).

\section{Anti-inflammatory and Antinociceptive Activity}

Lectin from Abelmoschus esculentus seeds showed activity in reducing zymosaninduced temporomandibular joint (TMJ) inflammatory hypernociception in rats along with the mechanism of action like reduced leukocyte influx along with MPO activity as well as lectin reduced TNF- $\alpha$ and IL-1 $\beta$ levels in temporomandibular joint inflammatory tissue and trigeminal ganglion, Which showed lectin exerts anti-inflammatory activity (Freitas $\boldsymbol{e t}$ al., 2016). Later lectin from the same plant Abelmoschus esculentus significantly reduced formalin-induced TMJ inflammatory hypernociception and decreased Evans blue extravasation. It decreased TNF- $\alpha$ levels in the TMJ tissue, trigeminal ganglion, and subnucleus caudalis. The lectin did not show antinociceptive effects in the presence of naltrindole or nor-binaltorphimine (Alves et al., 2018). Bauhinia monandra leaf lectin showed anti- inflammatory activity of $64 \%$ on paw edema induced by carrageenan as well as it also exert antinociceptive activity on mice (Campos $\boldsymbol{e}$ al., 2016). Lectins from Parkia platycephala showed antinociceptive activity in the mouse model of acetic acid induced and also demonstrated anti-inflammatory effect causing inhibition of leukocyte migration induced by both direct and indirect chemo attractants (Umaro et al., 2016). Crotalaria retusa L. seeds lectin inhibited the mice paw edema and neutrophil migration into the peritoneal cavity induced by carrageenan (Aragão et al., 2017). Lectin from Lonchocarpus campestris seeds inhibited paw edema and hyperalgesia induced by carrageenan as well as it showed antinociceptive activity in the behavioural tests of Formalin and Writhing (Pires et al., 2018).

\section{Anti-coagulant Activity}

Lectin purified from Bauhinia forficata seeds showed anticoagulant and antiplatelet properties. Coagulation time was increases in presence of Bauhinia forficata lectin and this consequence is not due to inhibition of human plasma kallikrein or human factor Xa. Dose dependent manner this lectin inhibits ADP and epinephrine-induced platelet aggregation. It was observed that at $3.0 \mu \mathrm{M}$ concentration this lectin completely inhibits the platelet aggregation (Silva $\boldsymbol{e t}$ al. 2012). Moringa oleifera seed lectin showed anticoagulant protein on in-vitro blood coagulation parameters and at least on activated partial thromboplastin by more than 300 Second and prothrombin times at a concentration ranging from 3 to 60 $\mu \mathrm{g} / \mathrm{mL}$ (Luz et al., 2013). Phthirusa pyrifolia leaves lectin showed anticoagulant activity. It was showed through coagulation times like activated partial thromboplastin time (APTT) and thrombin time (TT) extrinsic pathway (Costa et al., 2017)

\section{Immune Response Activity}

Lectin from banana was cloned and expressed after that it was injected in Balb/c (albino). This experiment showed increased IgG and IgM concentrations in dosedependent manners (Dimitrijevic et al., 2012). In the year 2016 same group showed banana lectin could be able to increase the concentration of $\operatorname{IgA}$ and $\operatorname{IgG}$ production in a dose-dependent manner(Marinković et al., 2016). One more recombinant banana lectin binds to murine peritoneal macrophages and affects their functional aspects. Lectin raised the production of IL-10, TGF $\beta$, IL-4 and enhancement of arginase activity with reduction of NO IL-12 formation
(Marinkovic et al., 2017). Again, another lectin from the fruit pulp of banana, when orally administered to the mice, they found that there were, no significant differences were found in the lymphocytes of mouse peripheral blood, although an increase of CD4+ and decrease of CD8+ T-cells were observed in the thymus However, they found that there were decrease in IL-6 and IFN $\gamma$ and increase of IL10, IL-17A and TNF $\alpha$ production in the peripheral blood of mice (Sansone $\boldsymbol{e t}$ al. 2016). B-chain of Korean mistletoe seeds lectin did not induce apoptosis in bone marrow-derived dendritic cells $\left(\mathrm{BMDC}_{\mathrm{s}}\right)$. Whereas the treatment of lectin on $\mathrm{BMDC}_{\mathrm{s}}$ increases the expressions of co-stimulatory molecules (CD40, CD80, CD86, and MHC II) and the secretions of cytokines (IL-1 $\beta$, IL-6, IL-12p70, and TNF- $\alpha$ ). The lectin induced naïve CD4+ T cell differentiation toward Th1 cells directly and indirectly (Kim et al., 2014). Lectin from the Onion (Allium cepa) plant bulb increase the production of NO (nitric oxide) up to 6-8-fold in macrophage cell line, RAW264.7 and rat peritoneal macrophages. It stimulated the production of cytokines (TNF- $\alpha$, IL-12, IFN- $\gamma$ and IL-2)) and furthermore enhanced the proliferation of murine thymocytes (Prasanna et al., 2015). Another onion lectin showed immune-protective properties by promoting the development of lymphoid cells count (WBC and lymphocytes count) and immune response in cyclophosphamide induced immune suppressed Wistar rats. Furthermore, it also depressed proinflammatory molecules like COX-2 and NO, and expression levels of immune regulatory molecule TNF- $\alpha$, and suppressed the Th2-type type cytokine, i.e., serum IL-10 (Kumar et al., 2016). Lectin from the inflorescence of Alpinia purpurata induced the release of cytokines belonging to Th1 (IFN- $\gamma$, TNF$\alpha$, and IL-6) and Th17 (IL-17A) profiles as well as of nitric oxide. It stimulated the production of IL-10 as well as activate both T CD8+ and $\mathrm{CD}^{4+}$ subsets of lymphocytes (Brito et al., 2017). Microgramma vacciniifolia fronds lectin induced immunomodulatory properties on human peripheral blood mononuclear cells (PBMCs) by increasing TNF $\alpha$, IFN $\gamma$, IL-6, IL-10, and nitric oxide production. It also stimulates T lymphocytes from PBMCs to differentiate into CD8+ cells (Leite et al., 2017). Lectin from the leaf pinnulae of Calliandra surinamensis activates immune cells in BALB/c mice splenocytes. They found that there were changes in in cytosolic calcium concentration $\left(\left[\mathrm{Ca}^{2+}\right] \mathrm{cyt}\right)$, mitochondrial membrane potentia $(\triangle \Psi \mathrm{m})$, and reactive oxygen species (ROS) levels associated with cell viability, proliferation, cytokine and nitric oxide production. It also promotes the production of IL-2 and TNF- $\alpha$ (Procópio et al., 2018).

\section{Mitogenic Activity}

In the case of Red Kidney Bean (Phaseolus vulgaris L.), wild-type lectin and irradiated ( $\gamma$-radiation) form lectins showed the mitogenic effect on lymphocyte proliferation. Authors found that the lectin after irradiation at $1 \mathrm{kGy}$ showed a decrease in mitogenic activity approx $70 \%$, Whereas at $10 \mathrm{kGy}$ showed complete mitogenic activity (Mallikarjunan et al., 2014).

\section{Glycoconjugates Research}

Anacardium occidentale bark lectin was Immobilization on $\mathrm{CNBr}$-Activated (cynogen bromide) Sepharose CL-4B. Bound feutin to this column demonstrated that lectin matrix could be used for glycoconjugates research (MacIel et al., 2012). The use of matrices (Sepharose CL-4B) containing Cratylia mollis lectins used for isolation of glycoproteins from fetal bovine serum, human colostrum, hen egg white, and human blood plasma (Santos-Filho et al., 2013). Lectin isolated from Platypodium elegans seeds when immobilized on CNBr-activated Sepharose 4B and showed feutin binding properties in solution, demonstrated that this lectin active and capable of binding carbohydrates (Alencar et al., 2017). Lectin extracted from Cratylia mollis seeds was immobilized on the surface of titanium dioxide nanotubes and found that increase in osteoblast-like cell adhesion on the TNTs-LbL-Cramoll (titanium dioxide nanotubes-layer by layer- Cratylia mollis seeds lectin) system when compared to the bare TNTs surfaces (Oliveira et al., 2018).

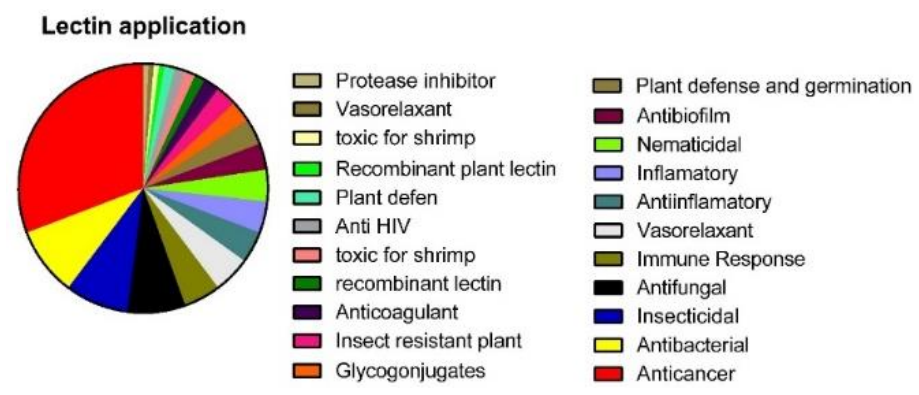

Figure 1 Application of lectins

\section{CONCLUSION}

Plant lectins are complex and carbohydrates binding proteins. The physiologica role of lectins in the plant is not clear. Although plant lectins differ in their amino acids sequences, structural aspect as well evolutionary origin but most of lectins exhibits similar type of function such as antibacterial, antifungal, insecticidal, anti- 
inflammatory (Figure 1). Due to easy availability and requirements simple purification system plants lectins will one of the best tools to study proteincarbohydrates interaction or useful disease biology.

Acknowledgement: Authors thank the Indian Council of Medical Research (ICMR) for research funding. S.K thanks SERB for financial assistance under the Fast-Track Scheme (SB/FT/LS-190/2012).

Conflict of interest: The authors declare that there is no conflict of interest.

\section{REFERENCES}

Ahmed, F. R. S., Amin, R., Hasan, I., Asaduzzaman, A. K. M., \& Kabir, S. R. (2017). Antitumor properties of a methyl- $\beta$-D-galactopyranoside specific lectin from Kaempferia rotunda against Ehrlich ascites carcinoma cells. International Journal of Biological Macromolecules, 102, 952-959. https://doi.org/ 10.1016/j.ijbiomac.2017.04.109

Albuquerque, L. P. de, Pontual, E. V., Santana, G. M. de S., Silva, L. R. S., Aguiar, J. dos S., Coelho, L. C. B. B., Rgo, M. J. B. de

M., Pitta, M. G. da R., Silva, T. G. da, Melo, A. M. M. de A., Napoleo, T. H., \& Paiva, P. M. G. (2014). Toxic effects of Microgramma vacciniifolia rhizome lectin on Artemia salina, human cells, and the schistosomiasis vector Biomphalaria glabrata. Acta Tropica, 23-27. https://doi.org/10.1016/j.actatropica.2014.06.005

Alencar, D., Pinto-junior, V. R., Hadson, A., Neco, B., Queiroz, M., Jose, V., Osterne, S., Freitas, A., Figueiredo, C., Gleiciane, M., Martins, Q., Luiz, J., Correia, A., Guimaraes, R., Bainy, R., Maria, A., Assreuy, S., Santiago, K., \& Sousa, B. (2017). Partial characterization and immobilization in CNBr-activated Sepharose of a native lectin from Platypodium elegans seeds ( PELa) and comparative study of edematogenic effect with the recombinant form. International Journal of Biological Macromolecules, 102, 323-330. https://doi.org/10.1016/j.ijbiomac.2017.03.193

Alves de Vasconcelos, M., Sena da Penha, S., Castro e Silva, V. R., Leite, T. A., Bezerra de Souza, E., Silva Souza, B. W., Teixeira, E. H., \& Coelho da Silva, A L. (2018). Fruticulosin: A novel type 2 ribosome-inactivating protein from Abrus fruticulosus seeds that exhibits toxic and antileishmanial activity. Archives of Biochemistry and Biophysics, 658, 46-53 https://doi.org/10.1016/j.abb.2018.09.001

Alves, S. M., Freitas, R. S., do Val, D. R., Vieira, L. V., de Assis, E. L., Gomes, F. I. F., Gadelha, C. A. de A., Gadelha, T. S., de Lacerda, J. T. J. G., ClementeNapimoga, J. T., Pinto, V. de P. T., Cristino Filho, G., Bezerra, M. M., \& Chaves, H. V. (2018). The efficacy of a lectin from Abelmoschus esculentus depends on central opioid receptor activation to reduce temporomandibular join hypernociception in rats. Biomedicine and Pharmacotherapy, 101, 478-484 https://doi.org/10.1016/j.biopha.2018.02.117

Ang, A. S. W., Cheung, R. C. F., Dan, X., Chan, Y. S., Pan, W., \& Ng, T. B. (2014) Purification and characterization of a glucosamine-binding antifungal lectin from Phaseolus vulgaris cv.

Chinese Pinto Beans with antiproliferative activity towards nasopharyngeal carcinoma cells. Applied Biochemistry and Biotechnology, 172(2), 672-686. https://doi.org/10.1007/s12010-013-0542-2

Aragão, D. P., da Silva Souza, B., de Brito, T. V., de Araújo Bastos Santana, L., de Paiva Silva, R. M., de Oliveira, A. P., da Cunha Pereira, A. C. T., Ferreira, G. P., dos Reis Barbosa, A. L., \& de Oliveira, J. S. (2017). The anti-inflammatory and antinociceptive activity of albumins from Crotalaria retusa seeds. Biomedicine and Pharmacotherapy, 93, 536-542. https://doi.org/10.1016/j.biopha.2017.06.078 Asaduzzaman, A. K. M., Hasan, I., Chakrabortty, A., Zaman, S., Islam, S. S. Ahmed, F. R. S., Kabir, K. M. A., Nurujjaman, M., Uddin, M. B., Alam, M. T., Shaha, R. K., \& Kabir, S. R. (2018). Moringa oleifera seed lectin inhibits Ehrlich ascites carcinoma cell growth by inducing apoptosis through the regulation of Bak and NF- $\mathrm{\kappa B}$ gene expression. International Journal of Biological Macromolecules 107, 1936-1944. https://doi.org/10.1016/j.ijbiomac.2017.10.070

Batista, J., Ralph, M., Vaz, R., Souza, P., Silva, A., Nascimento, D., Souza, L., Ramos, M., Mastroeni, P., \& Lima-Filho, J. (2017). Plant lectins ConBr and CFL modulate expression toll-like receptors, pro-inflammatory cytokines and reduce the bacterial burden in macrophages infected with Salmonella enterica serovar Typhimurium. Phytomedicine,

25 ,

$52-60$.

https://doi.org/10.1016/j.phymed.2016.12.005

Batista, K. L. R., Silva, C. R., Santos, V. F., Silva, R. C., Roma, R. R., Santos, A L. E., Pereira, R. O., Delatorre, P., Rocha, B. A. M., Soares, A. M. S., Costa-Júnior, L. M., \& Teixeira, C. S. (2018). Structural analysis and anthelmintic activity of Canavalia brasiliensis lectin reveal molecular correlation between the carbohydrate recognition domain and glycans of Haemonchus contortus. Molecular and Biochemical Parasitology, 225, 67-72. https://doi.org/10.1016/j.molbiopara.2018.09.002

Bayer, H., Essig, K., Stanzel, S., Frank, M., Gildersleeve, J. C., Berger, M. R., \& Voss, C. (2012). Evaluation of riproximin binding properties reveals a novel mechanism for cellular targeting. Journal of Biological Chemistry, 287(43), 35873-35886. https://doi.org/10.1074/jbc.M112.368548

Biosci, I. J., Alfarabi, M., Rosmalawati, S., \& Bintang, M. (2015).
Antiproliferation activity of tuber protein from Typhonium flagelliforme ( Lodd .) blume on MCF-7 cell line. International Journal of Biosciences 6, 52-60. https://doi.org/10.12692/ijb/6.12.52-60

Bobbili, K. B., Pohlentz, G., Narahari, A., Sharma, K., Surolia, A., Mormann, M., \& Swamy, M. J. (2018). Coccinia indica agglutinin, a 17 kDa PP2 like phloem lectin: Affinity purification, primary structure and formation of self-assembled filaments. International Journal of Biological Macromolecules, 108, 1227-1236. https://doi.org/10.1016/j.ijbiomac.2017.11.024

Bose, P. P., Bhattacharjee, S., Singha, S., Mandal, S., Mondal, G., Gupta, P., \& Chatterjee, B. P. (2016). A glucose/mannose binding lectin from litchi (Litchi chinensis) seeds: Biochemical and biophysical characterizations. Biochemistry and Biophysics Reports, 6, 242-252. https://doi.org/10.1016/j.bbrep.2016.05.001

Caccia, S., Van Damme, E. J. M., De Vos, W. H., \& Smagghe, G. (2012) Mechanism of entomotoxicity of the plant lectin from Hippeastrum hybrid (Amaryllis) in Spodoptera littoralis larvae. Journal of Insect Physiology, 58(9), 1177-1183. https://doi.org/10.1016/j.jinsphys.2012.05.014

Camaroti, J. R. S. L., de Almeida, W. A., do Rego Belmonte, B., de Oliveira, A P. S., de Albuquerque Lima, T., Ferreira, M. R. A., Paiva, P. M. G., Soares, L. A. L., Pontual, E. V., \& Napoleão, T. H. (2018). Sitophilus zeamais adults have survival and nutrition affected by Schinus terebinthifolius leaf extract and its lectin (SteLL). Industrial Crops and Products, 116, 81-89. https://doi.org/10.1016/j.indcrop.2018.02.065

Campos, J. K. L., Arajo, C. S. F., Arajo, T. F. S., Santos, A. F. S., Teixeira, J. A., Lima, V. L. M., \& Coelho, L. C. B. B. (2016). Anti-inflammatory and antinociceptive activities of Bauhinia monandra leaf lectin. Biochimie, 2, 62-68. https://doi.org/10.1016/j.biopen.2016.03.001

Carvalho, A. de S., da Silva, M. V., Gomes, F. S., Paiva, P. M. G., Malafaia, C. B., da Silva, T. D., Vaz, A. F. de M., da Silva, A. G., Arruda, I. R. de S., Napoleo, T. H., Carneiro-da-Cunha, M. das G., \& Correia, M. T. dos S. (2015). Purification, characterization and antibacterial potential of a lectin isolated from Apuleia leiocarpa seeds. International Journal of Biological Macromolecules, 75, 402 408. https://doi.org/10.1016/j.ijbiomac.2015.02.001

Cavada, B. S., Silva, M. T. L., Osterne, V. J. S., Pinto-Junior, V. R., Nascimento, A. P. M., Wolin, I. A. V., Heinrich, I. A., Nobre, C. A. S., Moreira, C. G., Lossio, C. F., Rocha, C. R. C., Martins, J. L., Nascimento, K. S., \& Leal, R. B. (2018) Canavalia bonariensis lectin: Molecular bases of glycoconjugates interaction and antiglioma potential. International Journal of Biological Macromolecules, 106, 369-378. https://doi.org/10.1016/j.ijbiomac.2017.08.023

Chan, Y. S., Xia, L., \& Ng, T. B. (2016). White kidney bean lectin exerts antiproliferative and apoptotic effects on cancer cells. International Journal of Biological Macromolecules, https://doi.org/10.1016/j.ijbiomac.2015.12.094

Costa, R. B., Campana, P. T., Chambergo, F. S., Napoleão, T. H., Paiva, P. M. G., Pereira, H. J. V., Oliva, M. L. V., \& Gomes, F. S. (2018). Purification and characterization of a lectin with refolding ability from Genipa americana bark International Journal of Biological Macromolecules, 119, 517-523. https://doi.org/10.1016/j.ijbiomac.2018.07.178

Costa, R. M. P. B., Albuquerque, W. W. C., Silva, M. C. C., Paula, R. A. de, Melo, M. S., Oliva, M. L. V., \& Porto, A. L. F. (2017). Can $\gamma$-radiation modulate hemagglutinating and anticoagulant activities of PpyLL, a lectin from Phthirusa pyrifolia. International Journal of Biological Macromolecules, 104, 125-136. https://doi.org/10.1016/j.ijbiomac.2017.06.007

Da Silva, Pollyanna Michelle, de Moura, M. C., Gomes, F. S., da Silva Trentin, D., Silva de Oliveira, A. P., de Mello, G. S. V., da Rocha Pitta, M. G., de Melo Rego, M. J. B., Coelho, L. C. B. B., Macedo, A. J., de Figueiredo, R. C. B. Q., Paiva, P. M. G., \& Napoleão, T. H. (2018). PgTeL, the lectin found in Punica granatum juice, is an antifungal agent against Candida albicans and Candida krusei. International Journal of Biological Macromolecules, 108, 391-400. https://doi.org/10.1016/j.ijbiomac.2017.12.039

Das, A., Roy, A., Hess, D., \& Das, S. (2013). Characterization of a Highly Potent Insecticidal Lectin from Colocasia esculenta Tuber and Cloning of Its Coding Sequence. American Journal of Plant Sciences, 4, 408-416. https://doi.org/10.4236/ajps.2013.42A053

Datta, D., Pohlentz, G., Schulte, M., Kaiser, M., Goycoolea, F. M., Mthing, J., Mormann, M., \& Swamy, M. J. (2016). Physico-chemical characteristics and primary structure of an affinity-purified $\alpha$-D-galactose-specific, jacalin-related lectin from the latex of mulberry (Morus indica). Archives of Biochemistry and Biophysics, 609, 59-68. https://doi.org/10.1016/j.abb.2016.09.009

De Andrade Luz, L., Rossato, F. A., Costa, R. A. P. e., Napoleão, T. H., Paiva, P. M. G., \& Coelho, L. C. B. B. (2017). Cytotoxicity of the coagulant Moringa oleifera lectin (cMoL) to B16-F10 melanoma cells. Toxicology in Vitro, 44, 94 99. https://doi.org/10.6036/8637

De Freitas Pires, A., Bezerra, M. M., Amorim, R. M. F., do Nascimento, F. L. F., Marinho, M. M., Moura, R. M., Silva, M. T. L., Correia, J. L. A., Cavada, B. S., Assreuy, A. M. S., \& Nascimento, K. S. (2019). Lectin purified from Lonchocarpus campestris seeds inhibits inflammatory nociception. International Journal of Biological Macromolecules, 125, 53-60. https://doi.org/10.1016/j.ijbiomac.2018.11.233

De Lacerda, J. T. J. G., e Lacerda, R. R., Assunção, N. A., Tashima, A. K., Juliano, M. A., dos Santos, G. A., dos Santos de Souza, M., de Luna Batista, J., Rossi, C. 
E., de Almeida Gadelha, C. A., \& Santi-Gadelha, T. (2017). New insights into lectin from Abelmoschus esculentus seeds as a Kunitz-type inhibitor and its toxic effects on Ceratitis capitata and root-knot nematodes Meloidogyne spp. Process Biochemistry, 63, 96-104. https://doi.org/10.1016/j.procbio.2017.09.003

De Medeiros, M. L. S., de Moura, M. C., Napoleão, T. H., Paiva, P. M. G., Coelho, L. C. B. B., Bezerra, A. C. D. S., \& da Silva, M. D. C. (2018). Nematicidal activity of a water soluble lectin from seeds of Moringa oleifera. International Journal of Biological Macromolecules, 108 ,

782-789.

\section{https://doi.org/10.1016/j.ijbiomac.2017.10.167}

De Oliveira, A. P. S., de Santana Silva, L. L., de Albuquerque Lima, T., Pontual, E. V., de Lima Santos, N. D., Breitenbach Barroso Coelho, L. C., do Amaral Ferraz Navarro, D. M., Zingali, R. B., Napoleo, T. H., \& Paiva, P. M. G. (2016) Biotechnological value of Moringa oleifera seed cake as source of insecticidal lectin against Aedes aegypti. Process Biochemistry, 51(10), 1683-1690. https://doi.org/10.1016/j.procbio.2016.06.026

De Oliveira Figueirôa, E., Aranda-Souza, M. Â., Varejão, N., Rossato, F. A., Costa, R. A. P., Figueira, T. R., da Silva, L. C. N., Castilho, R. F., Vercesi, A. E., \& dos Santos Correia, M. T. (2017). pCramoll and rCramoll lectins induce cell death in human prostate adenocarcinoma (PC-3) cells by impairment of mitochondrial homeostasis. Toxicology in Vitro, 43, 40-46. https://doi.org/10.1016/j.tiv.2017.05.016

De Santana Brito, J., Ferreira, G. R. S., Klimczak, E., Gryshuk, L., de Lima Santos, N. D., de Siqueira Patriota, L. L., Moreira, L. R., Soares, A. K. A., Barboza, B. R. Paiva, P. M. G., do Amaral Ferraz Navarro, D. M., de Lorena, V. M. B., de Melo, C. M. L., Coriolano, M. C., \& Napoleão, T. H. (2017). Lectin from inflorescences of ornamental crop Alpinia purpurata acts on immune cells to promote Th1 and Th17 responses, nitric oxide release, and lymphocyte activation. Biomedicine and Pharmacotherapy, 94, 865-872. https://doi.org/10.1016/j.biopha.2017.08.026 Deepa, M., \& Priya, S. (2012). Purification and Characterization of a Novel AntiProliferative Lectin from Morus alba L. Leaves. Protein \& Peptide Letters, 19(8), 839-845. https://doi.org/10.2174/092986612801619516

Deepa, M., Sureshkumar, T., Satheeshkumar, P. K., \& Priya, S. (2012). Purified mulberry leaf lectin (MLL) induces apoptosis and cell cycle arrest in human breas cancer and colon cancer cells. Chemico-Biological Interactions, 200(1), 38-44 https://doi.org/10.1016/j.cbi.2012.08.025

Del Rio, M., de la Canal, L., Pinedo, M., \& Regente, M. (2018). Internalization of a sunflower mannose-binding lectin into phytopathogenic fungal cells induces cytotoxicity. Journal of Plant Physiology, 221, 22-31. https://doi.org/10.1016/j.jplph.2017.12.001

Dimitrijevic, R., Stojanovic, M., Micic, M., Dimitrijevic, L., \& GavrovicJankulovic, M. (2012). Recombinant banana lectin as mucosal immunostimulator. Journal of Functional Foods, 4(3), 636-641. https://doi.org/10.1016/j.jff.2012.04.003

Faheina-Martins, G. V., da Silveira, A. L., Cavalcanti, B. C., Ramos, M. V., Moraes, M. O., Pessoa, C., \& Araújo, D. A. M. (2012). Antiproliferative effects of lectins from Canavalia ensiformis and Canavalia brasiliensis in human leukemia cell lines. Toxicology in Vitro, 26(7), 1161-1169. https://doi.org/10.1016/j.tiv.2012.06.017

Fernando, C., Oliveira, R. De, Celine, M., Moura, D., Henrique, T., Maria, P., Paiva, G., Cassandra, L., Barroso, B., Lígia, M., \& Macedo, R. (2017). A chitinbinding lectin from Moringa oleifera seeds ( WSMoL ) impairs the digestive physiology of the Mediterranean flour larvae, Anagasta kuehniella. Pesticide Biochemistry and Physiology, 1-10. https://doi.org/10.1016/j.pestbp.2017.01.006 Ferreira, G. R. S., Brito, J. de S., Procópio, T. F., Santos, N. D. de L., de Lima, B. J. R. C., Coelho, L. C. B. B., Navarro, D. M. do A. F., Paiva, P. M. G., Soares, T., de Moura, M. C., \& Napoleão, T. H. (2018). Antimicrobial potential of Alpinia purpurata lectin (ApuL): Growth inhibitory action, synergistic effects in combination with antibiotics, and antibiofilm activity. Microbial Pathogenesis, 124, 152-162. https://doi.org/10.1016/j.micpath.2018.08.027

Figueiredo, T., Leite, L., Patriota, D. S., Celine, M., Moura, D., Michelle, P., Patrícia, A., Oliveira, S. De, Soares, T., Diego, T., Cassandra, L., Barroso, B., Galdino, M., Jesus, M., Melo, B. De, Celia, R., Queiroz, B., Figueiredo, D., Maria, P., Henrique, T. (2017). CasuL: A new lectin isolated from Calliandra surinamensis leaf pinnulae with cytotoxicity to cancer cells , antimicrobial activity and antibiofilm effect. International Journal of Biological Macromolecules, 98 , 419-429. https://doi.org/10.1016/j.ijbiomac.2017.02.019

Freitas, R. S., do Val, D. R., Fernandes, M. E. F., Gomes, F. I. F., de Lacerda, J. T. J. G., SantiGadelha, T., de Almeida Gadelha, C. A., de Paulo Teixeira Pinto, V., Cristino-Filho, G., Pereira, K. M. A., de Castro Brito, G. A., Bezerra, M. M., \& Chaves, H. V. (2016). Lectin from Abelmoschus esculentus reduces zymosaninduced temporomandibular joint inflammatory hypernociception in rats via heme oxygenase-1 pathway integrity and tnf- $\alpha$ and il-1 $\beta$ suppression. International Immunopharmacology,

https://doi.org/10.1016/j.intimp.2016.06.012

Geethanandan, K., Joseph, A., Sadasivan, C., \& Haridas, M. (2013). Carbohydrate binding and unfolding of spatholobus parviflorus lectin: Fluorescence and circular dichroism spectroscopic study. Applied Biochemistry and Biotechnology, 171(1), 80-92. https://doi.org/10.1007/s12010-013-0340-x

Gemeiner, P., Mislovičová, D., Tkáč, J., Švitel, J., Pätoprstý, V., Hrabárová, E., Kogan, G., \& Kožár, T. (2009). Lectinomics. II. A highway to biomedical/clinical diagnostics. Biotechnology Advances,

$27(1)$

$1-15$ https://doi.org/10.1016/j.biotechadv.2008.07.003

Ghosh, P., Sen, S., Chakraborty, J., \& Das, S. (2016). Monitoring the efficacy of mutated Allium sativum leaf lectin in transgenic rice against Rhizoctonia solani. BMC Biotechnology, 16(1), 24. https://doi.org/10.1186/s12896-016-0246-0

Gondim, A. C. S., Romero-Canelón, I., Sousa, E. H. S., Blindauer, C. A., Butler, J. S., Romero, M. J., Sanchez-Cano, C., Sousa, B. L., Chaves, R. P., Nagano, C. S., Cavada, B. S., \& Sadler, P. J. (2017). The potent anti-cancer activity of Dioclea lasiocarpa lectin. Journal of Inorganic Biochemistry, 175, 179-189. https://doi.org/10.1016/j.jinorgbio.2017.07.011

Hou, F. J., Xu, H., \& Liu, W. Y. (2003). Simultaneous existence of cinnamomin (a type II RIP) and small amount of its free A- and B-chain in mature seeds of camphor tree. International Journal of Biochemistry and Cell Biology, 35(4), 455464. https://doi.org/10.1016/S1357-2725(02)00274-1

Islam, F., Gopalan, V., Lam, A. K. Y., \& Kabir, S. R. (2018). Pea lectin inhibits cell growth by inducing apoptosis in SW480 and SW48 cell lines. International Journal of Biological Macromolecules, 117(2017), 1050-1057. https://doi.org/10.1016/j.ijbiomac.2018.06.021

Jiménez, P., Gayoso, M., Tejero, J., Cabrero, P., Córdoba-Díaz, D., Basterrechea, J. E., \& Girbés, T. (2013). Toxicity in mice of lectin ebulin $\mathrm{f}$ present in dwarf Elderberry (Sambucus ebulus L.). Toxicon, 61(1), 26-29. https://doi.org/10.1016/j.toxicon.2012.10.009

Kabir, S. R., Nabi, M. M., Haque, A., Zaman, R. U., Mahmud, Z. H., \& Reza, M. A. (2013). Pea lectin inhibits growth of Ehrlich ascites carcinoma cells by inducing apoptosis and G2/M cell cycle arrest in vivo in mice. Phytomedicine, 20(14), 12881296. https://doi.org/10.1016/j.phymed.2013.06.010

Kim, B. S., Hwang, H. S., Park, H., \& Kim, H. H. (2015). Effects of selective cleavage of high-mannose-type glycans of Maackia amurensis leukoagglutinin on sialic acid-binding activity. Biochimica et Biophysica Acta - General Subjects, 1850(9), 1815-1821. https://doi.org/10.1016/j.bbagen.2015.05.011

Kim, J. J., Hwang, Y. H., Kang, K. Y., Kim, I., Kim, J. B., Park, J. H., Yoo, Y. C. \& Yee, S. T. (2014). Enhanced dendritic cell maturation by the B-chain of Korean mistletoe lectin (KML-B), a novel TLR4 agonist. International Immunopharmacology, https://doi.org/10.1016/j.intimp.2014.05.010

Klafke, G. B., Moreira, G. M. S. G., Pereira, J. L., Oliveira, P. D., Conceição, F. R., Lund, R. G., Grassmann, A. A., Dellagostin, O. A., \& da Silva Pinto, L. (2016) Lectin I from Bauhinia variegata (BVL-I) expressed by Pichia pastoris inhibits initial adhesion of oral bacteria in vitro. International Journal of Biological Macromolecules, 93, 913-918. https://doi.org/10.1016/j.ijbiomac.2016.09.062

Kumar, S., Kapoor, V., Gill, K., Singh, K., Xess, I., Das, S. N., \& Dey, S. (2014). Antifungal and antiproliferative protein from cicer arietinum: A bioactive compound against emerging pathogens. BioMed Research International, 2014, 1 9. https://doi.org/10.1155/2014/387203

Kumar, V. P., \& Venkatesh, Y. P. (2016). Alleviation of cyclophosphamideinduced immunosuppression in Wistar rats by onion lectin (Allium cepa agglutinin). Journal of Ethnopharmacology, 186, 280-288. https://doi.org/10.1016/j.jep.2016.04.006

Leal, R. B., Pinto-Junior, V. R., Osterne, V. J. S., Wolin, I. A. V., Nascimento, A P. M., Neco, A. H. B., Araripe, D. A., Welter, P. G., Neto, C. C., Correia, J. L. A. Rocha, C. R. C., Nascimento, K. S., \& Cavada, B. S. (2018). Crystal structure of DlyL, a mannose-specific lectin from Dioclea lasiophylla Mart. Ex Benth seeds that display cytotoxic effects against C6 glioma cells. International Journal of Biological Macromolecules, $\quad 114, \quad 64-76$ https://doi.org/10.1016/j.ijbiomac.2018.03.080

Leite, L., Patriota, D. S., Figueiredo, T., Santana, J. De, Sebag, V., Patrícia, A., Oliveira, S. De, Karine, A., Soares, D. A., Rafael, L., Albuquerque, T. De, Soares,

T., Diego, T., Maria, P., Paiva, G., Maria, V., Lorena, B. De, Lagos, M., Melo, D.,

. Henrique, T. (2017). Microgramma vacciniifolia ( Polypodiaceae ) fronds contain a multifunctional lectin with immunomodulatory properties on human cells. International Journal of Biological Macromolecules, 103, 36-46. http://dx.doi.org/10.1016/j.ijbiomac.2017.05.037

Luz, L. de A., Silva, M. C. C., Ferreira, R. da S., Santana, L. A., Silva-Lucca, R. A., Mentele, R., Oliva, M. L. V., Paiva, P. M. G., \& Coelho, L. C. B. B. (2013) Structural characterization of coagulant Moringa oleifera Lectin and its effect on hemostatic parameters. International Journal of Biological Macromolecules, 58, 31-38. https://doi.org/10.1016/j.ijbiomac.2013.03.044

$\mathrm{Ma}$, Q. H., Zhen, W. B., \& Liu, Y. C. (2013). Jacalin domain in wheat jasmonateregulated protein Ta-JA1 confers agglutinating activity and pathogen resistance. Biochimie, 95(2), 359-365. https://doi.org/10.1016/j.biochi.2012.10.014

MacIel, M. I. S., De Mendonça Cavalcanti, M. D. S., Napoleão, T. H., Paiva, P. M. G., De Almeida Catanho, M. T. J., \& Coelho, L. C. B. B. (2012). Anacardium occidentale bark lectin: Purification, immobilization as an affinity model and influence in the uptake of technetium-99M by rat adipocytes. Applied Biochemistry and Biotechnology, 168(3), 580-591. https://doi.org/10.1007/s12010-012-9798-1 Mallikarjunan, N., Marathe, S., Rajalakshmi, D., Mahesh, S., Jamdar, S. N., \& Sharma, A. (2014). Effect of ionizing radiation on structural and functional attributes of red kidney bean (Phaseolus vulgaris L.) lectin. LWT - Food Science and Technology, 59(1), 300-307. https://doi.org/10.1016/j.lwt.2014.04.052

Marinkovic, E., Djokic, R., Lukic, I., Filipovic, A., Inic-Kanada, A., Kosanovic, 
D., Gavrovic-Jankulovic, M., \& Stojanovic, M. (2017). Modulation of functional characteristics of resident and thioglycollate-elicited peritoneal murine macrophages by a recombinant banana lectin. PLOS ONE, 12(2), 1-21. https://doi.org/10.1371/journal.pone.0172469

Marinković, E., Lukić, I., Kosanović, D., Inić-Kanada, A., Gavrović-Jankulović, M., \& Stojanović, M. (2016). Recombinantly produced banana lectin isoform promotes balanced pro-inflammatory response in the colon. Journal of Functional Foods, 20, 68-78. https://doi.org/10.1016/j.jff.2015.10.019

Naik, S., \& Kumar, S. (2020). Biochemical Characterization of lactose binding entadin lectin from Entada rheedii seeds with cytotoxic activity against cancer cell $\begin{array}{llll}\text { lines. } & \text { Omega, } & \text { 5(27), } & \text { 16430-16439. }\end{array}$ https://doi.org/10.1021/acsomega.0c00577

Naik, S., Rawat, R. S., Khandai, S., Kumar, M., Jena, S. S., Vijayalakshmi, M. A., \& Kumar, S. (2017). Biochemical characterisation of lectin from Indian hyacinth plant bulbs with potential inhibitory action against human cancer cells International Journal of Biological Macromolecules, 105, 1349-1356. https://doi.org/10.1016/j.ijbiomac.2017.07.170

Napoleão, T. H., Belmonte, B. do R., Pontual, E. V., de Albuquerque, L. P., Sá, R. A., Paiva, L. M., Breitenbach Barroso Coelho, L. C., \& Paiva, P. M. G. (2013) Deleterious effects of Myracrodruon urundeuva leaf extract and lectin on the maize weevil, Sitophilus zeamais (Coleoptera, Curculionidae). Journal of Stored Products Research, 54, 26-33. https://doi.org/10.1016/j.jspr.2013.04.002

Napoleão, T. H., Gomes Dos Santos-Filho, T., Pontual, E. V., Da Silva Ferreira, R., Coelho, L. C. B. B., \& Paiva, P. M. G. (2013). Affinity matrices of Cratylia mollis seed lectins for isolation of glycoproteins from complex protein mixtures. Applied Biochemistry and Biotechnology, 171(3), 744-755 https://doi.org/10.1007/s12010-013-0403-Z

Nascimento, A. P. M., Knaut, J. L., Rieger, D. K., Wolin, I. A. V., Heinrich, I. A., Mann, J., Juarez, A. V., Sosa, L. del V., De Paul, A. L., Moreira, C. G., Silva, I. B., Nobre, C. S., Osterne, V. J. S., Nascimento, K. S., Cavada, B. S., \& Leal, R. B. (2018). Anti-glioma properties of DVL, a lectin purified from Dioclea violacea International Journal of Biological Macromolecules, 120, 566-577. https://doi.org/10.1016/j.ijbiomac.2018.08.106

Nascimento, K. S., Santiago, M. Q., Pinto-Junior, V. R., Osterne, V. J. S., Martins F. W. V., Nascimento, A. P. M., Wolin, I. A. V., Heinrich, I. A., Martins, M. G. Q., Silva, M. T. L., Lossio, C. F., Rocha, C. R. C., Leal, R. B., \& Cavada, B. S. (2017). Structural analysis of Dioclea lasiocarpa lectin: A C6 cells apoptosisinducing protein. International Journal of Biochemistry and Cell Biology, 92, 79 89. https://doi.org/10.1016/j.biocel.2017.09.014

Oliveira, C. T., Kunz, D., Silva, C. P., \& Macedo, M. L. R. (2015). Entomotoxic properties of Dioclea violacea lectin and its effects on digestive enzymes of Anagasta kuehniella (Lepidoptera). Journal of Insect Physiology, 81, 81-89. https://doi.org/10.1016/j.jinsphys.2015.07.007

Oliveira, W. F., Silva, G. M. M., Cabral Filho, P. E., Fontes, A., Oliveira, M. D L., Andrade, C. A. S., Silva, M. V., Coelho, L. C. B. B., Machado, G., \& Correia, M. T. S. (2018). Titanium dioxide nanotubes functionalized with Cratylia mollis seed lectin, Cramoll, enhanced osteoblast-like cells adhesion and proliferation Materials Science and Engineering $C, \quad 90, \quad 664-672$. https://doi.org/10.1016/j.msec.2018.04.089

Osterne, V. J. S., Silva-Filho, J. C., Santiago, M. Q., Pinto-Junior, V. R., Almeida A. C., Barreto, A. A. G. C., Wolin, I. A. V., Nascimento, A. P. M., Amorim, R. M. F., Rocha, B. A. M., Delatorre, P., Nagano, C. S., Leal, R. B., Assreuy, A. M. S., Nascimento, K. S., \& Cavada, B. S. (2017). Structural characterization of a lectin from Canavalia virosa seeds with inflammatory and cytotoxic activities International Journal of Biological Macromolecules, 94, 271-282. https://doi.org/10.1016/j.ijbiomac.2016.10.020

Ouyang, L., Chen, Y., Wang, X. Y., Lu, R. F., Zhang, S. Y., Tian, M., Xie, T., Liu, B., \& He, G. (2014). Polygonatum odoratum lectin induces apoptosis and autophagy via targeting EGFR-mediated Ras-Raf-MEK-ERK pathway in human MCF-7 breast cancer cells. Phytomedicine, 21(12), 1658-1665. https://doi.org/10.1016/j.phymed.2014.08.002

Palharini, J. G., Richter, A. C., Silva, M. F., Ferreira, F. B., Pirovani, C. P., Naves, K. S. C., Goulart, V. A., Mineo, T. W. P., Silva, M. J. B., \& Santiago, F. M. (2017) Eutirucallin: A lectin with antitumor and antimicrobial properties. Frontiers in Cellular and Infection Microbiology, 7, 1-13. https://doi.org/10.3389/fcimb.2017.00136

Panda, P. K., Mukhopadhyay, S., Behera, B., Bhol, C. S., Dey, S., Das, D. N., Sinha, N., Bissoyi, A., Pramanik, K., Maiti, T. K., \& Bhutia, S. K. (2014) Antitumor effect of soybean lectin mediated through reactive oxygen speciesdependent pathway. Life Sciences, 111(1), 27-35 https://doi.org/10.1016/j.1fs.2014.07.004

Pereira de Albuquerque, L., Maria de Sá Santana, G., Pontual, E. V., Napoleão, T. H., Breitenbach Barroso Coelho, L. C., \& Paiva, P. M. G. (2012). Effect of Microgramma vaccinifolia rhizome lectin on survival and digestive enzymes of Nasutitermes corniger (Isoptera, Termitidae). International Biodeterioration and Biodegradation, 75, 158-166. https://doi.org/10.1016/j.ibiod.2012.06.030

Pinto, V. R., De Santiago, M. Q., Da Silva Osterne, V. J., Correia, J. L. A., Pereira, F. N., Cajazeiras, J. B., De Vasconcelos, M. A., Teixeira, E. H., Do Nascimento, A. S. F., Miguel, T. B. A. R., De Castro Miguel, E., Sampaio, A. H., Do Nascimento, K. S., Nagano, C. S., \& Cavada, B. S. (2013). Purification, partial characterization and immobilization of a mannose-specific lectin from seeds of Dioclea lasiophylla mart. Molecules, 18(9), 10857-10869. https://doi.org/10.3390/molecules180910857

Polito, L., Bortolotti, M., Battelli, M. G., Calafato, G., \& Bolognesi, A. (2019). Ricin: An ancient story for a timeless plant toxin. Toxins, 11(6), 1-16. https://doi.org/10.3390/toxins11060324

Prasanna, V. K., \& Venkatesh, Y. P. (2015). Characterization of onion lectin (Allium cepa agglutinin) as an immunomodulatory protein inducing Th1-type immune response in vitro. International Immunopharmacology, 26(2), 304-313. https://doi.org/10.1016/j.intimp.2015.04.009

Procópio, T. F., de Siqueira Patriota, L. L., da Silva Barros, B. R., de Souza Aguiar, L. M., de Lorena, V. M. B., Paiva, P. M. G., de Melo, C. M. L., \& Napoleão, T. H. (2018). Calliandra surinamensis lectin (CasuL) does not impair the functionality of mice splenocytes, promoting cell signaling and cytokine production. Biomedicine and Pharmacotherapy, 107, 650-655. https://doi.org/10.1016/j.biopha.2018.08.043

Quiroga, A. V., Barrio, D. A., \& Añón, M. C. (2015). Amaranth lectin presents potential antitumor properties. LWT - Food Science and Technology, 60(1), 478485. https://doi.org/10.1016/j.1wt.2014.07.035

Rafiq, S., Majeed, R., Qazi, A. K., Ganai, B. A., Wani, I., Rakhshanda, S., Qurishi, Y., Sharma, P. R., Hamid, A., Masood, A., \& Hamid, R. (2013). Isolation and antiproliferative activity of Lotus corniculatus lectin towards human tumour cell lines.

Phytomedicine, 21(1),

$30-38$

https://doi.org/10.1016/j.phymed.2013.08.005

Rahimi, V., Hajizadeh, J., Zibaee, A., \& Jalali Sendi, J. (2018). Toxicity and physiological effects of an extracted lectin from Polygonum persicaria L. on Helicoverpa armigera (Hübner) (Lepidoptera: Noctuidae). Physiological and

Molecular Plant Pathology,

101 ,

$38-44$. https://doi.org/10.1016/10.1016/j.pmpp.2017.09.005

Ríos-de Álvarez, L., Jackson, F., Greer, A. W., Grant, G., Jackson, E., Morrison, A. A., \& Huntley, J. F. (2012). Direct anthelmintic and immunostimulatory effects of oral dosing semi-purified phytohaemagglutinin lectin in sheep infected with Teladorsagia circumcincta and Trichostrongylus colubriformis. Veterinary Parasitology, $187(1-2)$,

267-274 https://doi.org/10.1016/10.1016/j.vetpar.2012.01.005

Rodrigues Lacerda, R., Silva do Nascimento, E., Thalles Jocelino Gomes de Lacerda, J., da Silva Pinto, L., Rizzi, C., Marques Bezerra, M., Ribeiro Pinto, I., Mateus Pereira Filho, S., de Paulo Texeira Pinto, V., Cristino Filho, G., Alberto de Almeida Gadelha, C., \& Santi Gadelha, T. (2016). G Model Lectin from seeds of a Brazilian lima bean variety (Phaseolus lunatus L. var. cascavel) presents antioxidant, antitumour and gastroprotective activities. International Journal of Biological Macromolecules, 95, https://doi.org/10.1016/10.1016/j.ijbiomac.2016.10.097

Roy, U. K., Lavignac, N., Rahman, A. M., \& Nielsen, B. V. (2018). Purification of lectin and Kunitz trypsin inhibitor from soya seeds. Journal of Chromatographic Science, 1-7. https://doi.org/10.1016/10.1093/chromsci/bmy018

Saha, R. K., Acharya, S., Jamiruddin, M., \& Roy, P. (2014). Antimicrobial effects of a crude plant lectin isolated from the stem of Tinospora tomentosa. The Journal of Phytopharmacology, 3(1), 44-51.

Sansone, A. C. M. B., Sansone, M., dos Santos Dias, C. T., \& Oliveira do Nascimento, J. R. (2016). Oral administration of banana lectin modulates cytokine profile and abundance of T-cell populations in mice. International Journal of Biological Macromolecules 89 $19-24$ https://doi.org/10.1016/j.ijbiomac.2016.04.049

Santi-Gadelha, T., Rocha, B. A. M., Gadelha, C. A. A., Silva, H. C., Castellon, R. E. R., Gonçalves, F. J. T., Toyama, D. O., Toyama, M. H., de Souza, A. J. F., Beriam, L. O. S., Martins, J. L., Joazeiro, P. P., \& Cavada, B. S. (2012). Effects of a lectin-like protein isolated from Acacia farnesiana seeds on phytopathogenic bacterial strains and root-knot nematode. Pesticide Biochemistry and Physiology, 103(1), 15-22. https://doi.org/10.1016/j.pestbp.2012.02.003

Santos, N. D. L., Napoleão, T. H., Benevides, C. A., Albuquerque, L. P., Pontual, E. V., Oliveira, A. P. S., Coelho, L. C. B. B., Navarro, D. M. A. F., \& Paiva, P. M G. (2018). Effect of gamma irradiation of Moringa oleifera seed lectin on its larvicidal, ovicidal, and oviposition-stimulant activities against Aedes aegypti. South African Journal of Botany, 1-6. https://doi.org/10.1016/j.sajb.2018.05.001 Shanmugavel, S., Velayutham, V., Kamalanathan, T., Periasamy, M., Munusamy, A., \& Sundaram, J. (2016). Isolation and analysis of mannose/trehalose/maltose specific lectin from jack bean with antibruchid activity. International Journal of Biological Macromolecules,

91

$1-14$ https://doi.org/10.1016/j.ijbiomac.2016.05.093

Sharma, M., Reddy, H. V., Sindhura, B. R., Kamalanathan, A. S., Swamy, B. M. \& Inamdar, S. R. (2017). Purification, characterization and biological significance of mannose binding lectin from Dioscorea bulbifera bulbils. International Journal of Biological $\quad$ Macromolecules, $102, \quad 1146-1155$ https://doi.org/10.1016/j.ijbiomac.2017.04.085

Sharon, N. (2008). Lectins: Past, present and future. Biochemical Society Transactions, 36(6), 1457-1460. https://doi.org/10.1042/BST0361457

Sharon, N., \& Lis, H. (2004). History of lectins: From hemagglutinins to biological $\begin{array}{lll}\text { recognition molecules. } & \text { Glycobiology, } & \text { 14(11), }\end{array}$ https://doi.org/10.1093/glycob/cwh122 
Shivamadhu, M. C., Srinivas, B. K., Jayarama, S., \& Angatahalli Chandrashekaraiah, S. (2017). Anti-cancer and anti-angiogenic effects of partially purified lectin from Praecitrullus fistulosus fruit on in vitro and in vivo model Biomedicine and Pharmacotherapy, 96, 1299-1309. https://doi.org/10.1016/j.biopha.2017.11.082

Silva, A. F. B., Matos, M. P. V, Ralph, M. T., Silva, D. L., De Alencar, N. M. Ramos, M. V., \& Lima-Filho, J. V. (2016). Comparison of immunomodulatory properties of mannose-binding lectins from Canavalia brasiliensis and Cratylia argentea in a mice model of Salmonella infection. International Immunopharmacology, 31 ,

233-238 https://doi.org/10.1016/j.intimp.2015.12.036

Silva, F. de O., Santos, P. das N., FigueirÔa, E. de O., de Melo, C. M. L., de Andrade Lemoine Neves, J. K., Arruda, F. V. S., Cajazeiras, J. B., do Nascimento, K. S., Teixeira, E. H., Cavada, B. S., Porto, A. L. F., \& Pereira, V. R. A. (2014) Antiproliferative effect of Canavalia brasiliensis lectin on B16F10 cells. Research in Veterinary Science, 96(2), 276-282. https://doi.org/10.1016/j.rvsc.2014.01.005 Silva, H. C., Pinto, L. D. S., Teixeira, E. H., Nascimento, K. S., Cavada, B. S., \& Silva, A. L. C. (2014). BUL: A novel lectin from Bauhinia ungulata L. seeds with fungistatic and antiproliferative activities. Process Biochemistry, 49(2), 203-209. https://doi.org/10.1016/j.procbio.2013.10.020

Silva, M. C. C., De Paula, C. A. A., Ferreira, J. G., Paredes-Gamero, E. J., Vaz, A M. S. F., Sampaio, M. U., Correia, M. T. S., \& Oliva, M. L. V. (2014). Bauhinia forficata lectin (BfL) induces cell death and inhibits integrin-mediated adhesion on MCF7 human breast cancer cells. Biochimica et Biophysica Acta - General Subjects, 1840(7), 2262-2271. https://doi.org/10.1016/j.bbagen.2014.03.009

Silva, M. C. C., Santana, L. A., Mentele, R., Ferreira, R. S., De Miranda, A., SilvaLucca, R. A., Sampaio, M. U., Correia, M. T. S., \& Oliva, M. L. V. (2012). Purification, primary structure and potential functions of a novel lectin from Bauhinia forficata seeds. Process Biochemistry, 47(7), 1049-1059. https://doi.org/10.1016/j.procbio.2012.03.008

Silva, Pollyanna M., Napoleão, T. H., Silva, L. C. P. B. B., Fortes, D. T. O., Lima T. A., Zingali, R. B., Pontual, E. V., Araújo, J. M., Medeiros, P. L., Rodrigues, C. G., Gomes, F. S., \& Paiva, P. M. G. (2016). The juicy sarcotesta of Punica granatum contains a lectin that affects growth, survival as well as adherence and invasive capacities of human pathogenic bacteria. Journal of Functional Foods, 27, 695-702. https://doi.org/10.1016/j.jff.2016.10.015

Sindhura, B. R., Hegde, P., Chachadi, V. B., Inamdar, S. R., \& Swamy, B. M (2017). High mannose N-glycan binding lectin from Remusatia vivipara (RVL) limits cell growth, motility and invasiveness of human breast cancer cells Biomedicine and Pharmacotherapy, 93, 654-665. https://doi.org/10.1016/j.biopha.2017.06.081

Siritapetawee, J., Limphirat, W., Wongviriya, W., Maneesan, J., \& Samosornsuk, W. (2018). Isolation and characterization of a galactose-specific lectin (EantH) with antimicrobial activity from Euphorbia antiquorum L. latex. International Journal of Biological Macromolecules, 120, 1846-1854. https://doi.org/10.1016/j.ijbiomac.2018.09.206

Thakur, K., Kaur, T., Singh, J., Rabbani, G., Khan, R. H., Hora, R., \& Kaur, M. (2017). Sauromatum guttatum lectin: Spectral studies, lectin-carbohydrate interaction, molecular cloning and in silico analysis. International Journal of Biological Macromolecules, 104, 1267-1279. https://doi.org/10.1016/j.ijbiomac.2017.06.123

Umaro, A., Queiroz, M., Jose, V., Osterne, S., Pinto-junior, V. R., Paulo, L., Silvafilho, J. C., Debray, H., Anderson, B., Rocha, M., Delatorre, P., Souza, C., Correia, C., Maria, A., Assreuy, S., Santiago, K., \& Sousa, B. (2016). Lectins from Parkia biglobosa and Parkia platycephala: A comparative study of structure and biological effects. International Journal of Biological Macromolecules, 92, 194 201. https://doi.org/10.1016/j.ijbiomac.2016.07.032

Van Hove, J., Stefanowicz, K., De Schutter, K., Eggermont, L., Lannoo, N., Al Atalah, B., \& Van Damme, E. J. M. (2014). Transcriptional profiling of the lectin ArathEULS3 from Arabidopsis thaliana toward abiotic stresses. Journal of Plant Physiology, 171(18), 1763-1773. https://doi.org/10.1016/j.jplph.2014.08.009

Van Hove, Jonas, De Jaeger, G., De Winne, N., Guisez, Y., \& Van Damme, E. J. M. (2015). The Arabidopsis lectin EULS3 is involved in stomatal closure. Plant Science, 238, 312-322. https://doi.org/10.1016/j.plantsci.2015.07.005

Vigneshwaran, V., Thirusangu, P., Madhusudana, S., Krishna, V., Pramod, S. N., \& Prabhakar, B. T. (2016). The latex sap of the 'Old World Plant' Lagenaria siceraria with potent lectin activity mitigates neoplastic malignancy targeting neovasculature and cell death. International Immunopharmacology, 39, 158-171. https://doi.org/10.1016/j.intimp.2016.07.024

Villanueva, J., Quirós, L. M., \& Castañón, S. (2015). Purification and partial characterization of a ribosome-inactivating protein from the latex of Euphorbia trigona Miller with cytotoxic activity toward human cancer cell lines. Phytomedicine, 22(7-8), 689-695. https://doi.org/10.1016/j.phymed.2015.04.006 Vishweshwaraiah, Y. L., Prakash, B., \& Gowda, L. R. (2018). Expression profiling of the Dolichos lablab lectin during germination and development of the seed Plant Physiology and Biochemistry, 124, 10-19. https://doi.org/10.1016/j.plaphy.2017.12.040

Wu, J., Wang, J., Wang, S., \& Rao, P. (2016). Lunatin, a novel lectin with antifungal and antiproliferative bioactivities from Phaseolus lunatus billb International Journal of Biological Macromolecules, 89(2), 717-724. https://doi.org/10.1016/j.ijbiomac.2016.04.092

Wu, L., Liu, T., Xiao, Y., Li, X., Zhu, Y., Zhao, Y., Bao, J., \& Wu, C. (2016) Polygonatum odoratum lectin induces apoptosis and autophagy by regulation of microRNA-1290 and microRNA-15a-3p in human lung adenocarcinoma A549 cells. International Journal of Biological Macromolecules, 85, 217-226. https://doi.org/10.1016/j.ijbiomac.2015.11.014

Xiao, X., He, H., Ding, X., Yang, Q., Liu, X., Liu, S., Rang, J., Wang, T., Zuo, M., $\&$ Xia, L. (2015). Purification and cloning of lectin that induce cell apoptosis from Allium chinense. $\quad$ Phytomedicine, 22(2), 238-244 https://doi.org/10.1016/j.phymed.2014.12.004

Zárate, G., Sáez, G. D., \& Chaia, A. P. (2017). Dairy propionibacteria prevent the proliferative effect of plant lectins on SW480 cells and protect the metabolic activity of the intestinal microbiota in vitro. Anarobe, 44, 58-65. https://doi.org/10.1016/j.anaerobe.2017.01.012

Zhou, W., Gao, Y., Xu, S., Yang, Z., \& Xu, T. (2014). Purification of a mannosebinding lectin Pinellia ternata agglutinin and its induction of apoptosis in Bel-7404 cells. Protein Expression and Purification, 93, 11-17. https://doi.org/10.1016/j.pep.2013.09.018 